\title{
4. MIOCENE TUFF FROM MARIANA BASIN, LEG 129, SITE 802: A FIRST DEEP-SEA OCCURRENCE OF THAUMASITE ${ }^{1}$
}

\author{
Anne Marie Karpoff, ${ }^{2}$ Christian France-Lanord, ${ }^{3}$ François Lothe, ${ }^{3}$ and Philippe Karcher ${ }^{2}$
}

\begin{abstract}
Drilling at Ocean Drilling Program Site 802 in the central Mariana Basin, northwest Pacific Ocean, revealed an unexpected 222-m-thick sequence of well-cemented tuff of Miocene age. The deposits are unusual in that their source is presumably an unmapped seamount and they exhibit several peculiar petrological and mineralogical features. The well-developed secondary mineral sequence which includes analcime is rare in such relatively young, unburied deposits, in an area where there is little other evidence of hydrothermal activity. The massive tuff section also contains abundant fissure veins made of a rare silicate carbonate sulfate hydroxide hydrate of calcium, called thaumasite, which has not before been described in deep submarine deposits. The smectite-zeolite-thaumasite paragenesis coincides with the presence of chloride and calcium-enriched interstitial waters. The diagenetic evolution of the deposit appears to have been largely controlled by the depositional mode. The discharges of disaggregated and rejuvenated volcaniclasts seem to have been abrupt and repeated. The Miocene tuff at Site 802 thus provides new insights on the interactions between basaltic glass, biogenic phases, and seawater, in a specific deep-sea environment.
\end{abstract}

\section{INTRODUCTION}

Site 802 , in the central part of the Mariana Basin $\left(12^{\circ} 5.7^{\prime} \mathrm{N}\right.$, $153^{\circ} 12.6^{\prime} \mathrm{E}$ ) at $5969 \mathrm{~m}$ water depth (Fig. 1), was devoted (as were the previous Sites 800 and 801 ) to the search for Jurassic oceanic crust (Lancelot, Larson, et al., 1990), but provided unexpected results. The igneous basement penetrated at 509 mbsf at Site 802 consists of extrusive basalt overlain by upper Aptian-Albian claystone; the overlying sedimentary section is dominated by redeposited material suggesting massive lateral transport (Fig. 2). This sequence includes a thick Miocene tuff, consisting of well-indurated hyaloclastites and volcaniclastic turbidites. These deposits interrupted the deposition of brown pelagic clay which is ubiquitous at such depths for the same period in surrounding deep Pacific basins. This tuff also exhibits a peculiar secondary feature, abundant horizontal fracturing between 42.9 and $168.3 \mathrm{mbsf}$. The fractures, from a half millimeter to several centimeters thick, are filled with zeolites and an unusual mineral, thaumasite, which is a calcium silicate carbonate sulfate hydroxide hydrate. The purpose of this study is to establish the main mineralogi$\mathrm{cal}$ characteristics of the tuff and to correlate the unusual secondary mineral associations to related interstitial water profiles.

\section{CENOZOIC REDEPOSITED SEQUENCE}

\section{Lithologic Units}

From bottom to top in Hole $802 \mathrm{~A}$, the sedimentary sequence comprises the following lithologic units above the basaltic basement penetrated first at 509 mbsf (Shipboard Scientific Party, 1990): $49.2 \mathrm{~m}$ of Cenomanian to upper Aptian-Albian brown claystone, volcaniclastic turbidites, calcareous claystone, claystone, and radiolarite (Units IX to VI); $110.8 \mathrm{~m}$ of Campanian volcaniclastic turbidites, claystone, silty claystone, and porcellanite (Unit V); $19.3 \mathrm{~m}$ of Maestrichtian zeolitic pelagic claystone (Unit IV); $92.5 \mathrm{~m}$ of upper Paleocene to lower Miocene redeposited nannofossil chalk (Unit III); $222.8 \mathrm{~m}$ of Miocene tuff with redeposited claystone and chalk

\footnotetext{
'Larson, R. L., Lancelot, Y., et al., 1992. Proc. ODP, Sci. Results, 129: College Station, TX (Ocean Drilling Program)

${ }^{2}$ Centre de Géochimie de la Surface-CNRS, Institut de Géologie, 1 rue Blessig, 67084 Strasbourg Cedex, France.

${ }^{3}$ Centre de Recherches Pétrographiques et Géochimiques-CNRS, BP 20, 54501 Vandoeuvre Cedex, France.
}

(Unit II); and $14.6 \mathrm{~m}$ of upper Pliocene to Quaternary pelagic brown clay, poorly recovered (Unit I).

These units provide some evidence of the sedimentation events which took place in the northwestern Pacific, such as the middle Cretaceous volcanic event which is diachronously recorded at the nearby Deep Sea Drilling Project (DSDP) and Ocean Drilling Program (ODP) Sites 585, 462, 800, and 801 (Lancelot, Larson, et al., 1990; Karpoff, this volume). As at Sites 800 and 801, the sedimentary history at Site 802 is related to motion of the Pacific plate; since the middle Cretaceous, background pelagic sedimentation changed from radiolarian clay to clay with few radiolarians and nannofossils (when the site was nearest the equator), and to pelagic red clay rich in metal oxyhydroxides. The upper Cretaceous and Cenozoic condensed deepsea facies is well represented at Sites 800 and 801 in the Pigafetta Basin by lithologic Units I, respectively $38.0 \mathrm{~m}$ and $63.8 \mathrm{~m}$ thick. At Site 802 deposition of this facies, which forms lithologic Units IV and I, was interrupted by the accumulation of turbidites, mass flows, and grain flows of pelagic chalk, shallow-water carbonate debris, and subsequent volcaniclasts, which form the thick lithologic Units III and II (Fig. 2). Within the tuff (Unit II), the background pelagic sedimentation is commonly revealed as interturbidite clayey horizons, such as those occurring in Cores $802 \mathrm{~A}-13 \mathrm{R}$ and $-19 \mathrm{R}$.

\section{Characteristics of Miocene Tuff}

The petrological characteristics and the mode of deposition of the lower Miocene to middle Pliocene tuff give the basis of the thaumasite genesis problem and of the presumed volcanic source of the deposit as well.

\section{Biostratigraphy and Paleoenvironment}

Biostratigraphic dating of the Site 802 Cenozoic deposits is difficult because the fauna are heavily reworked; the occurrence of several hiatus is suspected, with the longest being from Maestrichtian through the earliest Paleocene and from the Eocene through the early Miocene (Shipboard Scientific Party, 1990). Sedimentation rates are similarly difficult to estimate and the minimum deposition rate of lithologic Unit II, including slowly sedimented claystone and rapidly deposited mass flows, is about $15 \mathrm{~m} / \mathrm{m}$.y.

Interpretation of paleomagnetic data suggests that Site 802 was moving northward across $5^{\circ} \mathrm{N}$ latitude during the Miocene. Water 


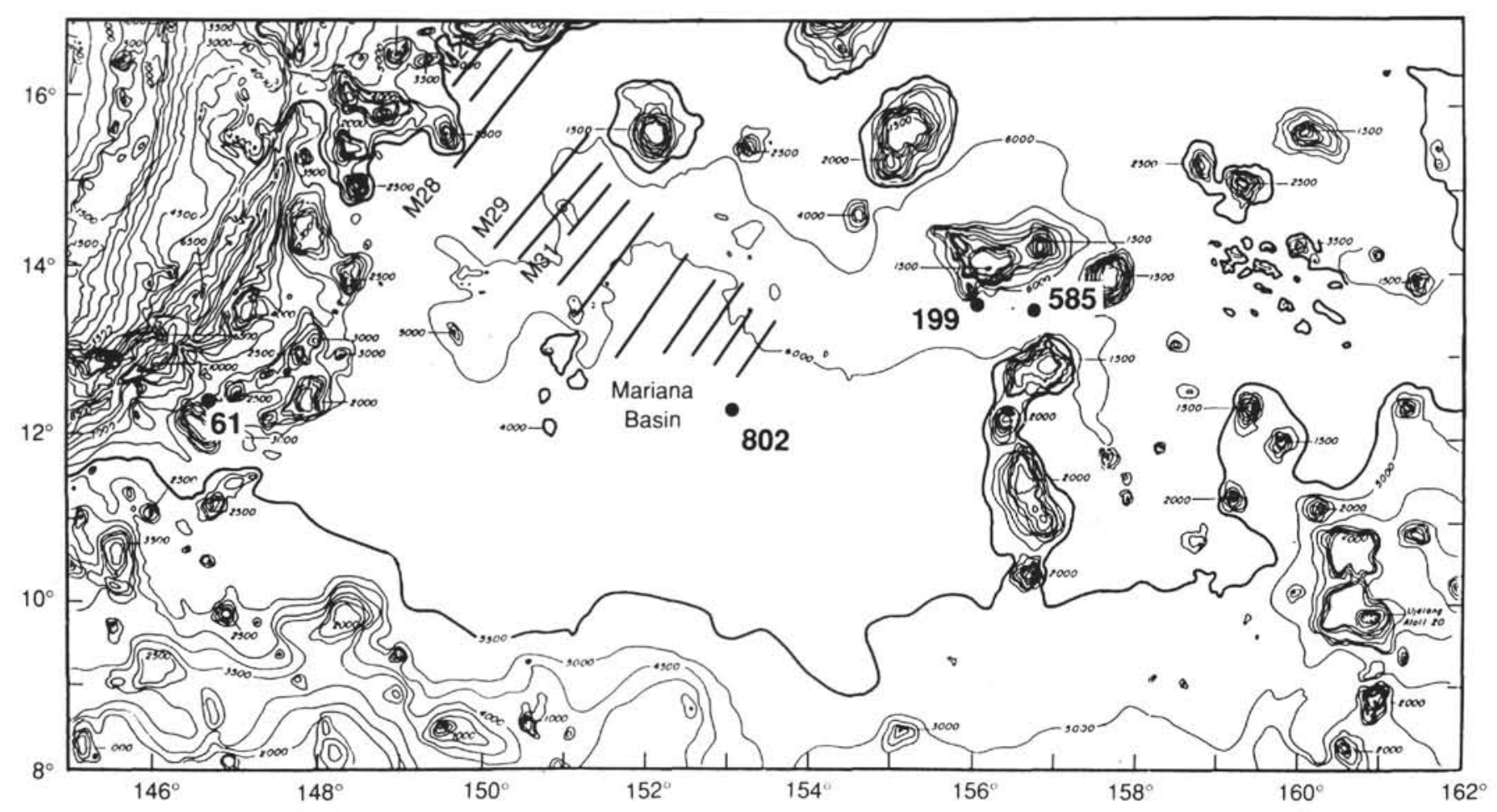

Figure 1. Location map of Site 802 and the magnetic lineation of the Mariana Basin. Also shown are DSDP sites. Bathymetry in meters (after Lancelot, Larson, et al., 1990).

depths reached 5000 to $6000 \mathrm{~m}$ during the same period (Shipboard Scientific Party, 1990). The composition of the bioclasts at the base of the Miocene sequence indicates that the original source of the reworked material was above sea level.

\section{Lithology and Petrology}

Two lithologic subunits, with a gradational transition, were established in the tuff.

Subunit IIB (160.6-237.41 mbsf) comprises the lower part of the sequence, with a gradational transition into underlying Unit III. Volcaniclastic input is intercalated with redeposited massive chalk and clayey chalk, comprising bioclasts including foraminifers, bryozoans, algae, and even wood fragments. The tuff is grayish green to gray, and was deposited as mass flows and grains flows, which formed meter-scale and fining upward beds. The crystal-vitric tuff consists of scarce clinopyroxene (5\%), abundant igneous rock fragments (up to $20 \%$ ), and abundant glass $(70 \%)$.

Subunit ПА (14.6-160.6 mbsf) comprises the upper part of the tuff and includes intercalated brown to green pelagic claystone. The very dark tuff was deposited as mass flows, grain flows, and turbidites, and is poorly sorted; rough bedding and grain sizes increase upward with very massive beds at the top of the sequence. Isolated lapilli occur in the tuff matrix or concentrated in beds such as in the upper part of the sequence (Core $802 \mathrm{~A}-4 \mathrm{R}$ ); grains are surrounded by clayey or calcitic and oxide-rich ash matrix. The tuff ranges from crystal-vitric to vitric-lithic, and contains in highly variable proportions, angular fresh glass shards, igneous rock fragments, and occasional tachylite. The glass is vesicular, sometimes spherulitic. The tuff contains subhedral feldspar, augite and olivine crystals. Fresh glass shards and altered vesicular glass clasts commonly coexist.

In both units, observed sedimentary structures includes planar and cross laminations, flame structures, pipe fluid escape features (Cores 802A-7R and -10R), scattered microfaults, and deformed beds (Cores
802A-19R and -23R). The secondary minerals (smectites, zeolites, calcite, and oxides) may constitute $20 \%$ to $50 \%$ of the rock (see below). Palagonite is well developed in the uppermost section (14.6 to 25.4 mbsf) where manganese oxide dendrites also occur. A peculiarity of the sequence is a well-expressed horizontal fracturing (Fig. 3) ranging from thin fissures less than a millimeter thick to pluricentrimetric massive veins. The white fillings are polyphased zeolites and/or thaumasite; the latter was earlier described as anhydrite (Shipboard Scientific Party, 1990).

\section{Interstitial Water Chemistry}

Interstitial water concentration profiles from Site 802 exhibit unusual trends (Shipboard Scientific Party, 1990; France-Lanord et al., this volume). From 22 to 83 mbsf there is a drastic increase in salinity, $\mathrm{Cl}, \mathrm{Ca}$, and $\mathrm{Sr}$ and almost complete depletions in $\mathrm{Mg}, \mathrm{K}, \mathrm{SO}_{4}$, and alkalinity. Below $83 \mathrm{mbsf}$, concentrations of these species are roughly constant through the lower part of the tuff and the uppermost clayey calcareous horizons of underlying Unit III. Silica concentration is relatively low in the tuff and increases in the underlying deposits. Intense diagenetic transformations, which overwhelm diffusion to and from overlying seawater, were interpreted to be responsible for these concentration profiles (France-Lanord et al., 1991; Karpoff et al., 1991).

\section{SAMPLES AND ANALYTICAL PROCEDURES}

\section{Samples}

Thirty samples and split fragments, including matrix and fracture filling, were taken from various lithologies in Unit II (Table 1). Some samples are the unsqueezed bulk fraction of interstitial water (IW) samples. Four samples from the top of underlying Unit III were also taken to examine the gradational mineralogical and chemical transitions between the units. 


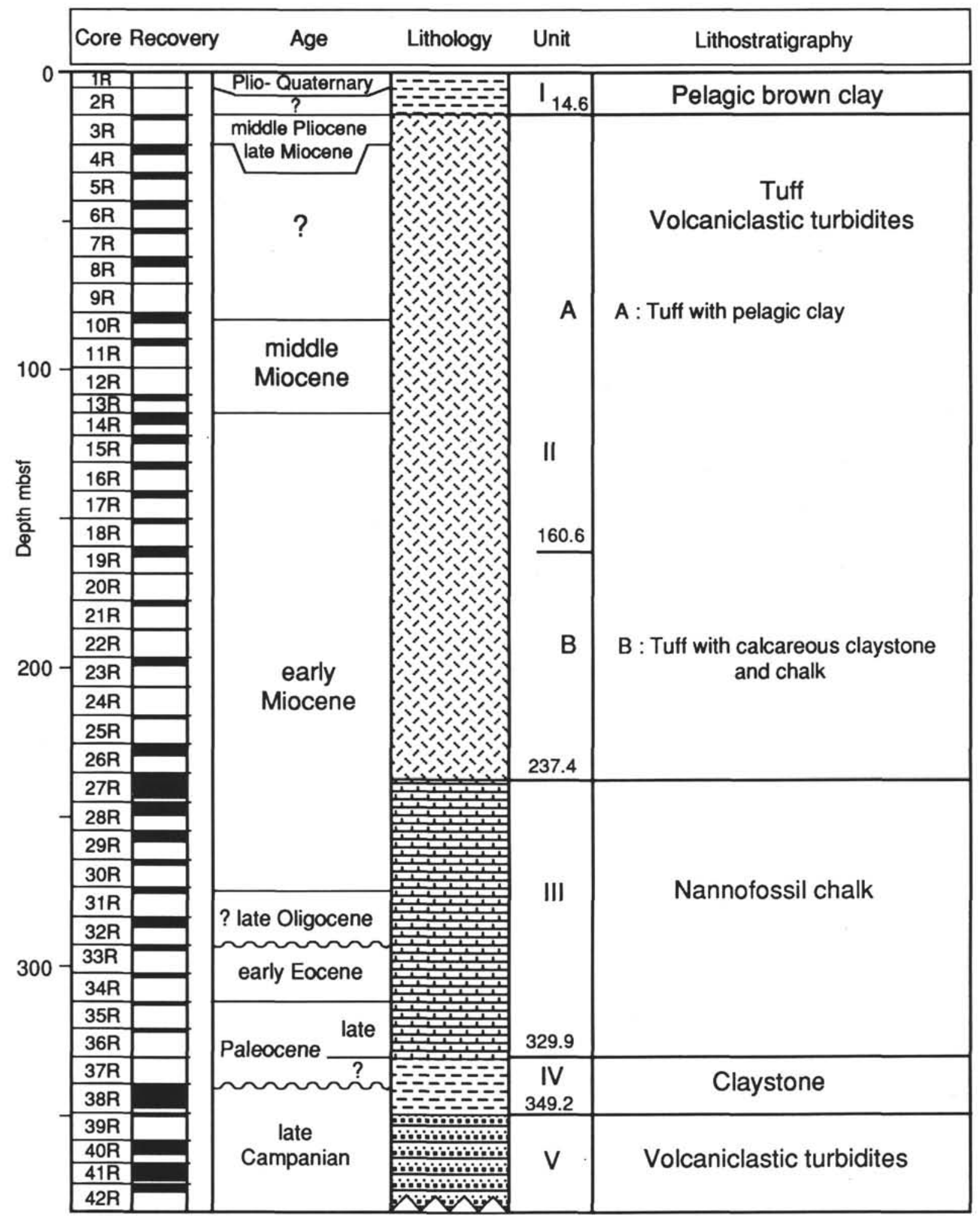

Figure 2. Stratigraphic summary of the upper Campanian to Quaternary lithologic units from Site 802 (from Shipboard Scientific Party, 1990).

A color change from yellowish brown to dark greenish gray is characteristic of the uppermost section, occurring between Samples $802 \mathrm{~A}-4 \mathrm{R}-1,4-7 \mathrm{~cm}$, and $-4 \mathrm{R}-1,140-150 \mathrm{~cm}$. The six shallowest samples (Cores 802A-3R and -4R) are similar in composition and were taken from a planar-laminated facies; these samples are palagonitized and show enrichments in manganese oxides in the form of vertical, upward-oriented dendrites. Samples from the base of Core $802 A-4 R$ are lapilli of fine-grained ash and rounded lapilli of volcaniclastic greenish gray claystone within a calcite-rich matrix. The dark, massive, and cemented tuff is represented by Samples $802 \mathrm{~A}-5 \mathrm{R}-1,128-132 \mathrm{~cm}$, through $-8 \mathrm{R}-2,132-136 \mathrm{~cm}$, and $802 \mathrm{~A}-14 \mathrm{R}-2,23-26 \mathrm{~cm}$, through -21R$1,70-74 \mathrm{~cm}$. Within this interval, some samples are from fracture fillings; 

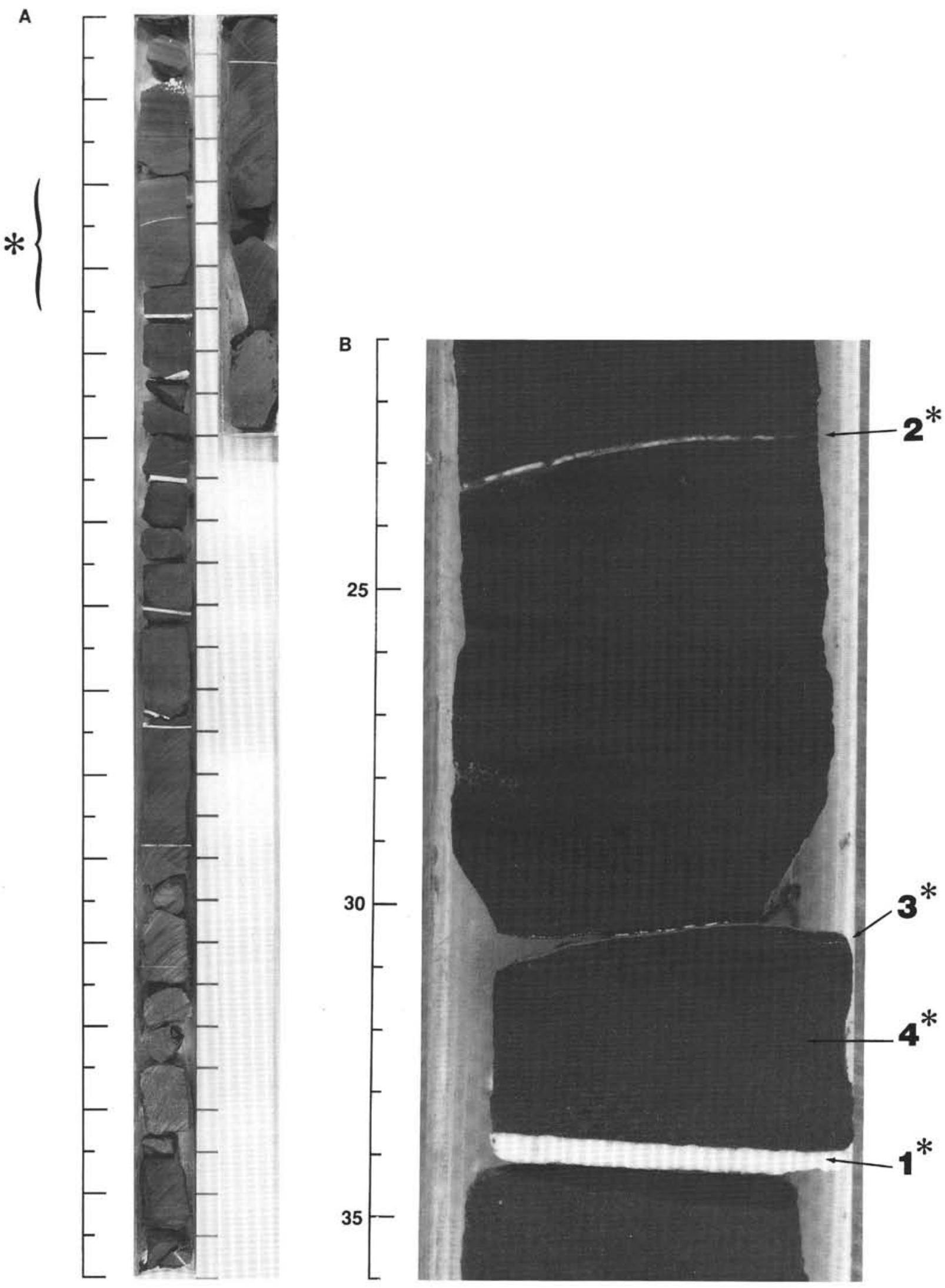

Figure 3. A. Photograph of the Sections 129-802A-16R-1 and -16R-2 (131.1-133.1 mbsf) with numerous horizontal thaumasite-filled fractures in the dark tuff. Asterisk ${ }^{*}$ ): enlarged section in (B). B. Photograph of the fine-grained black tuff (interval 129-802A-16R-1, 20-35 cm), with light cross-cut laminations, showing three types of fissure veins: (1) thaumasite-filled larger fracture; (2) chabazite and thaumasite-filled thin fracture; (3) thinner fissure coated by chabazite-type zeolite crystals; bulk tuff containing prevalent phillipsite; and (4) analcime. The asterisk (*) shows studied samples from vein types 1 and 3. 
Table 1. Studied samples from the tuff Unit II and from the top of clayey chalk sequence (Unit III) from Site 802.

\begin{tabular}{|c|c|c|c|c|}
\hline $\begin{array}{l}\text { Samples }(\mathrm{cm}) \\
129-802 A-\end{array}$ & $\begin{array}{l}\text { Depth } \\
\text { (mbsf) }\end{array}$ & Unit & Lithology and Description & Color \\
\hline $3 R-1,42-45$ & 15.02 & \multirow{22}{*}{ II-A } & \multirow{9}{*}{$\begin{array}{l}\text { T; altered, silty clay } \\
\text { T; altered, silty clay } \\
\text { PC; slightly tuffaceous } \\
\text { T; silt } \\
\text { T; altered, clayey } \\
\text { T; altered, clayey } \\
\text { LT; silty clay } \\
\text { LT; rounded lapilli (clayey) } \\
\text { T; silty sand, massive }\end{array}$} & \multirow{7}{*}{$\begin{array}{l}\text { 10YR 5/8 yellowish brown } \\
\text { 10YR } 5 / 8 \text { with abundant Mn dentrites } \\
10 \text { YR } 3 / 2 \text { very dark grayish brown } \\
\text { 2.5YR } 6 / 4 \text { light yellowish brown } \\
\text { 10YR } 5 / 8 \text { yellowish brown with Mn dentrites } \\
10 \text { YR } 5 / 8 \text { yellowish brown with Mn dentrites } \\
5 Y \text { 6/2 light olive gray }\end{array}$} \\
\hline $3 R-1,42-45(M n)$ & 15.03 & & & \\
\hline $3 R-1,106-109$ & 15.66 & & & \\
\hline $4 \mathrm{R}-1,0-3$ & 24.30 & & & \\
\hline $4 R-1,4-7$ & 24.34 & & & \\
\hline $4 \mathrm{R}-1,80-83$ & 25.10 & & & \\
\hline $4 \mathrm{R}-1,140-150$ (a) & 25.70 & & & \\
\hline $4 \mathrm{R}-2,2-6$ & 25.82 & & & \multirow{2}{*}{$\begin{array}{l}5 Y 6 / 2 \text { grains in } 7.5 Y R \quad 4 / 6 \text { brown and white matrix } \\
5 Y 3 / 1 \text { very dark olive gray }\end{array}$} \\
\hline $5 \mathrm{R}-1,128-132$ & 34.98 & & & \\
\hline $6 R-1,36-40$ & 43.26 & & \multirow{2}{*}{$\begin{array}{l}\text { LT; sand } \\
\text { T: silt }\end{array}$} & Black to $5 Y 3 / 1$ very dark olive gray \\
\hline $7 R-1,95-97$ & 53.35 & & & $5 Y 5 / 2$ olive gray \\
\hline $8 R-2,132-136$ & 64.72 & & \multirow{2}{*}{$\begin{array}{l}\text { T; altered, poorly sorted } \\
\text { Fracture filling }\end{array}$} & $10 Y 3 / 3-4 / 2$ dark to dark grayish brown \\
\hline $10 \mathrm{R}-1,4-5(\mathrm{~F})$ & 80.44 & & & White, opaque, ovoid centimetric sample \\
\hline $13 R-1,43-45$ & 108.73 & & \multirow{2}{*}{$\begin{array}{l}\text { PC; well-compacted } \\
\text { PC; well-compacted }\end{array}$} & 10YR $3 / 2$ very dark grayish brown \\
\hline $13 R-1,53-58$ (a) & 108.83 & & & 10YR $3 / 2$ very dark grayish brown \\
\hline $13 \mathrm{R}-2,30-32$ & 109.18 & & \multirow{2}{*}{$\begin{array}{l}\mathrm{PC} \text {; well-compacted } \\
\mathrm{T} \text {; sandy silt }\end{array}$} & $\begin{array}{l}\text { 10YR } 3 / 2 \text { very dark grayish brown } \\
\text { 10YR } 2 / 2 \text { very dark brown }\end{array}$ \\
\hline $14 \mathrm{R}-2,23-26$ & 116.13 & & & $2.5 Y 4 / 2$ dark grayish brown \\
\hline $16 \mathrm{R}-1,30-33(\mathrm{~F})$ & 131.40 & & \multirow{2}{*}{$\begin{array}{l}\text { Frature filling, fine: } 0.5 \mathrm{~mm} \\
\mathrm{~T} \text {; sandy silt }\end{array}$} & Translucent, white, with crystals \\
\hline $16 \mathrm{R}-1,30-33$ & 131.41 & & & $2.5 Y 5 / 2$ grayish brown \\
\hline $16 \mathrm{R}-1,30-33(\mathrm{~F})$ & 131.43 & & \multirow{2}{*}{$\begin{array}{l}\text { Fracture filling, } 4 \mathrm{~mm} \\
\mathrm{~T} \text {; sandy sitt }\end{array}$} & \\
\hline $17 R-1,108-113$ & 141.48 & & & $2.5 Y 5 / 2$ grayish brown \\
\hline $19 R-1,27-29$ & 159.37 & & \multirow{2}{*}{$\begin{array}{l}\text { T- C; silty clay, soft } \\
\text { T- C; clayey, soft }\end{array}$} & 2.5 Y $4 / 2$ dark grayish brown \\
\hline $19 R-2,30-32$ & 160.90 & \multirow{8}{*}{ II-B } & & \multirow{2}{*}{$\begin{array}{l}2.5 Y 7 / 2 \text { light gray } \\
5 Y R 4 / 1 \text { dark gray }\end{array}$} \\
\hline $19 R-2,67-72$ & 161.27 & & $\mathrm{~T}$; clay & \\
\hline $21 R-1,70-74$ & 178.30 & & T- C; silty clay & 5YR 4/1 dark gray \\
\hline $22 R-1,21-25$ & 187.21 & & $T ;$ sandy to silty clay, firm & $5 Y R 4 / 2$ olive gray $\& 2.5 Y R 6 / 2$ light brown gray \\
\hline $23 \mathrm{R}-1,14-17$ & 196.54 & & C-T; firm & \multirow{2}{*}{$\begin{array}{l}2.5 Y R 6 / 2 \text { light brownish gray } \\
2.5 Y R 6 / 2 \text {, with thin blue gray and green laminae }\end{array}$} \\
\hline $25 \mathrm{R}-1,49-52$ & 216.19 & & C; firm & \\
\hline $26 \mathrm{R}-1,120-124$ & 226.60 & & Ck; tuffaceous, clayey, soft & 10YR 5/2 grayish brown with darker streaks \\
\hline $26 \mathrm{R}-3,52-55$ & 228.92 & & Ck; clayey, soft & $10 \mathrm{YR} 7 / 3$ very pale brown \\
\hline $27 R-2,128-131$ & 237.88 & \multirow[t]{4}{*}{ III } & Ck; clayey & \multirow{4}{*}{$\begin{array}{l}5 Y 7 / 3 \text { pale yellow } \\
10 Y R 3 / 2 \& 7 / 3 \text { very dark gray \& very pale brown } \\
7.5 Y R 5 / 4 \text { brown } \\
7.5 Y R 7 / 2 \text { pinkish gray }\end{array}$} \\
\hline 27R-5, 12-14 & 241.22 & & C; calcareous & \\
\hline $27 \mathrm{R}-5,123-126$ (dark) & 242.33 & & C; calcareous, firm, dark & \\
\hline 27R-5, $123-126$ (clear) & 242.35 & & C; calcareous, clear & \\
\hline
\end{tabular}

Notes: Units from Shipboard Scientific Party (1990). T = tuff; LT = lapilli tuff; PC = pelagic clay; $C=$ claystone; $C k=$ chalk. All tuff and lapilli tuff samples are very well cemented and compacted.

Color of dried samples are slightly lighter than those given for the wet cores in Shipboard Scientific Party, 1990.

(a): IWTF sample (cf. France-Lanord et al., this volume).

one is a thick filling, rounded as an ovoid nodule by the effect of drilling, and made of a homogeneous white luster mineral; a second is from a medium-sized fracture and a third is a thin half-millimeter fracture showing white and translucent crystalline phases (Fig. 3). The samples from Core $802 \mathrm{~A}-13 \mathrm{R}$ are dark pelagic claystone rich in siliceous biogenic compounds. The gradational change between Subunits IIA and IIB is expressed by lighter color and lower compaction of samples from Cores 802A-19R to -21R. Lowermost Samples 802A-22R-1, $21-25 \mathrm{~cm}$, through $-26 \mathrm{R}-3,52-55 \mathrm{~cm}$, represent the more clayey and progressively more calcareous tuff basal section of Subunit IIB. Within this interval Sample 802A-25R-1, 49-52 cm, is an indurated layer made of several very thin laminae with alternating colors of brown, light brown, and blue gray.

\section{Methods}

\section{Mineralogical Investigations}

$\mathrm{X}$-ray diffraction (XRD) analyses were made on powdered samples using a Phillips PW1710 diffractometer. Samples were run between $3^{\circ}$ and $65^{\circ} 2 \theta$ at $40 \mathrm{kV} / 20 \mathrm{~mA}$, using CuK $\alpha$ radiation, a Ni filter, and a scan speed of $1 \% \mathrm{~min}$. For a few samples, the clay fraction $(<2 \mu \mathrm{m})$ was separated and X-ray diffraction analysis was run on four types of oriented aggregates: (1) untreated, (2) ethylene-glycol treated, (3) hydrazine treated, and (4) heated $\left(4 \mathrm{hr}\right.$ at $\left.490^{\circ} \mathrm{C}\right)$. For the clay analyses the following diffractometer conditions were used: $\mathrm{CoK} \alpha$ radiation, Fe filter, $40 \mathrm{kV} / 20 \mathrm{~mA}, 0.2^{\circ}-1^{\circ}$ slits and $1^{\circ} 2 \theta$ per min scan speed. The determination of the phases is based on the ASTM-JCPDS powder files in general and on the data of Gottardi and Galli (1985) for zeolites. On the powder X-ray diagrams the position of the (060) diffraction peak from abundant clay minerals allows dioctahedral and trioctahedral clays to be discriminated. Mineralogical identification was also made from microscopic observations of the thin sections and of the coarse fractions $(>63 \mu \mathrm{m})$, and from energy-dispersive X-ray (EDX) microprobe investigations (with "Tracor" detector) on fragments of samples observed under a JEOL JSM840 scanning electron microscope (SEM).

Bulk mineralogical composition of the tuff is given in Table 2, with some results on isolated phases from the fracture fillings and on few clay fractions. Quantitative XRD data is problematical in such polyphased heterogeneous facies (Eberhart, 1989). The relative abundances of mineral phases were estimated from the height of the 
Table 2. Mineralogical composition of the samples from Cenozoic tuff and clayey chalk, Site 802.

\begin{tabular}{|c|c|c|c|c|c|c|c|c|c|c|c|}
\hline \multirow{2}{*}{$\begin{array}{l}\text { Samples (cm) } \\
129-802 A .\end{array}$} & \multirow{2}{*}{$\begin{array}{l}\text { Depth } \\
\text { (mbsf) }\end{array}$} & \multicolumn{8}{|c|}{ Bulk Rock Composition } & \multirow{2}{*}{$\begin{array}{l}\text { Clay Fraction } \\
(\% \text { mineral }))\end{array}$} & \multirow{2}{*}{$\begin{array}{c}\text { Mineral } \\
\text { Association }\end{array}$} \\
\hline & & Q. & Phillip. & Clinop. & Analc. & Calcite & Clays & \multirow{2}{*}{ Vol. } & Others & & \\
\hline $3 R-1,42-45$ & 15.02 & & 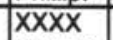 & & & & $x$ & & & & \\
\hline $3 R-1,42-45(M n)$ & 15.03 & & $x x x x x$ & & & & 0 & 0 & Rhodocrosite & & \\
\hline $3 R-1,106-109$ & 15.66 & $x$ & $x x x$ & 0 & & & $x$ & $x$ & Halite & $\operatorname{Sm}(80), I(10), K(10)$ & \\
\hline $4 \mathrm{R}-1,0-3$ & 24.30 & & $x x x x$ & & & & $x$ & 0 & & Sm: very broad peaks & \\
\hline $4 R-1,4-7$ & 24.34 & & $x x x x x$ & & & & 0 & 0 & & & 1 \\
\hline $4 R-1,80-83$ & 25.10 & 0 & $x x x x$ & & & & 0 & $x$ & & & \\
\hline $4 \mathrm{R}-1,140-150$ & 25.70 & & $x x$ & 0 & & $x$ & $x X$ & 0 & & & \\
\hline $4 \mathrm{R}-2,2-6$ & 25.82 & & $x$ & 0 & & $x x$ & $x x$ & 0 & & Sm (100): peak at $15 \AA$ & \\
\hline $5 R-1,128-132$ & 34.98 & & $x$ & & & & $x x x$ & $x$ & & & \\
\hline $6 R-1,36-40$ & 43.26 & 0 & $\mathrm{x}$ & & $\mathrm{x}$ & & $X X X$ & 0 & & Sm (100): peak at $13 \AA$ & \\
\hline $7 R-1,95-97$ & 53.35 & 0 & 0 & & $x x$ & & $x x x$ & 0 & & & 2 \\
\hline $8 R-2,132-136$ & 64.72 & & $x$ & & $x x$ & 10 & $x x$ & 0 & & & \\
\hline $10 R-1,4-5(F)$ & 80.44 & & & & & & & & Thaumasite & & \\
\hline $13 R-1,43-45$ & 108.73 & 0 & 0 & $X X X$ & & & $\mathrm{XX}$ & & Halite & Sm (95), I (5), Clinop. & \\
\hline 13R-1, $53-58$ & 108.83 & & & $x x$ & & & $x x x$ & & Halite & & 5 \\
\hline $13 R-2,30-32$ & 109.18 & 0 & 0 & $x x x$ & & 0 & $x x$ & 0 & Halite & Sm $(100)$ at $15 \AA$, Clinop. & \\
\hline $14 \mathrm{R}-2,23-26$ & 116.13 & & 0 & & $x X$ & & $\overline{X X X}$ & 0 & & & \\
\hline $16 R-1,30-33(F)$ & 131.40 & & & & & & & & Herschelite and & Gmelinite & \\
\hline $16 \mathrm{R}-1,30-33$ & 131.41 & & $x$ & & $x x$ & & $x x$ & 0 & & & \\
\hline $16 R-1,30-33(F)$ & 131.43 & & & & & & & & Thaumasite and & Chabazite & \\
\hline $17 R-1,108-113$ & 141.48 & 0 & 0 & & $x x$ & & $x x x$ & 0 & Chabazite & & 2 \\
\hline $19 \mathrm{R}-1,27-29$ & 159.37 & & 0 & & $x x x$ & & $x x$ & 0 & & & \\
\hline $19 R-2,30-32$ & 160.90 & & 0 & & $x x$ & & $x x x$ & & & & \\
\hline 19R-2, 67-72 & 161.27 & & $x$ & & $x$ & & $x x$ & $x$ & & & \\
\hline $21 R-1,70-74$ & 178.30 & & $x x$ & & 0 & & $x X$ & $x$ & & & \\
\hline $22 R-1,21-25$ & 187.21 & 0 & $x x$ & & 0 & & $x x x$ & 0 & & & \\
\hline $23 R-1,14-17$ & 196.54 & & $x x$ & & 0 & $x$ & $x x$ & & & & 3 \\
\hline $25 R-1,49-52$ & 216.19 & & $x x$ & & & $x$ & $x x$ & 0 & & & \\
\hline $26 \mathrm{R}-1,120-124$ & 226.60 & & $x$ & & $x$ & $x x$ & $x$ & & & & \\
\hline $26 \mathrm{R}-3,52-55$ & 228.92 & 0 & $x$ & 0 & & $\mathrm{XxX}$ & $X$ & 0 & & & 4 \\
\hline 27R-2, 128-131 & 237.88 & & 8 & $\overline{0}$ & & $\overline{x X X X}$ & 0 & $\overline{0}$ & & & \\
\hline $27 R-5,12-14$ & 241.22 & $x$ & $x$ & $x$ & & & $x x$ & & & & \\
\hline $27 R-5,123-126$ (dark) & 242.33 & $x x$ & & $x$ & & & $x x$ & $x$ & & & \\
\hline 27R-5, 123-126 (clear) & 242.35 & 0 & $\mathrm{x}$ & $x$ & & $x x$ & $\mathrm{x}$ & 0 & & & \\
\hline
\end{tabular}

Notes: Bulk rock: Q. = quartz; Phillip. = phillipsite; Clinop. = clinoptilolite; Analc. = analcime; Vol. = volcanogenic phases: pyroxene, olivine, feldspar. Relative abundance: $0 \leq 10 \% ; X \approx 20 \%$

Clay Fraction $(<2 \mu \mathrm{m}): \mathrm{Sm}=$ smectites; I = illite $(10 \AA$ phase $) ; \mathrm{K}=$ kaolinite; Clinop. = clinoptilolite.

main XRD peaks and their variations compared to the previous and next samples.

\section{Chemical Analyses}

Bulk chemical analyses were run on the same set of samples. Prior to elemental analysis, samples were dried at $110^{\circ} \mathrm{C}$ and melted in a mixture of lithium tetraborate then introduced into a glycolated solvent. Major element analyses were performed following the method of Besnus and Rouault (1973) using arc spectrometry and an ARL quantimeter. $\mathrm{Na}$ and $\mathrm{K}$ contents were determined by emission spectrometry. Major elements are expressed in weight percentage of oxides (wt \%) for $100 \mathrm{~g}$ of dried sample and with a relative precision of $\pm 2 \%$. Trace elements were determined using an inductively coupled plasma technique (ICP-35000-ARL) (Samuel et al., 1985). The relative precision for minor elements (in ppm) is $\pm 10 \%$. Results are given in Tables 3 and 4.

\section{MINERAL ASSEMBLAGES}

Based on the secondary mineral associations, five stages in the diagenetic evolution of the volcaniclastic deposits were identified. Beyond this preliminary study, microprobe analyses of secondary mineral and glass and HRTEM (high-resolution transmission electron microscopy) identification and microanalysis of the various smectites, are in progress for a further study and modelling of the chemical reactions involved in the alteration and diagenetic evolution.

\section{Massive Tuff and Volcaniclastic Clay}

Primary volcanogenic phases such as olivine, augite, and rarer plagioclase, are present throughout Unit II in variable proportions. Plagioclase is nearly absent in the cemented massive tuff (Cores 802A-6R to -19R). Quartz occurs in place and is more abundant in the uppermost light brown, manganese and palagonite-rich tuff horizon, where trace amounts of rhodochrosite are believed present (Core 802A-3R). In the lowermost part of Unit II, primary biogenic calcite increases in abundance down to the underlying chalk of Unit III; calcite is also common in samples from Core $802 \mathrm{~A}-4 \mathrm{R}$, where it is a recrystallized intergranular phase. Halite is abundant in the dried samples from the pelagic clay interval (Core 802A-13R).

In the tuff, secondary phases comprise abundant zeolites and clay minerals. The prevalent zeolites are phillipsite, clinoptilolite, and analcime. Small amounts of chabazite occur in places. Smectite minerals are ubiquitous, except in the uppermost $10 \mathrm{~m}$ of the unit where they are poorly crystallized and associated with trace amounts of an illitic mineral and kaolinite. Smectites exhibit a (060) reflection peak located at $1.50-1.51 \AA$ in the more pelagic horizons (Cores 
Table 3. Chemical composition of the bulk samples from Cenozoic tuff and clayey chalk, Site 802: major elements (weight percentage of oxides).

\begin{tabular}{|c|c|c|c|c|c|c|c|c|c|c|c|c|c|c|c|}
\hline $\begin{array}{l}\text { Samples (cm): } \\
\text { 129-802A- }\end{array}$ & $\begin{array}{l}\text { Depth } \\
\text { (mbsf) }\end{array}$ & Unit & \begin{tabular}{|c|} 
Mineral \\
Assoc.
\end{tabular} & $\mathrm{SiO} 2$ & $\mathrm{Al} 2 \mathrm{O} 3$ & $\mathrm{MgO}$ & $\mathrm{CaO}$ & $\mathrm{Fe} 2 \mathrm{O}$ & $\mathrm{Mn} 304$ & $\mathrm{TiO} 2$ & $\mathrm{Na} 2 \mathrm{O}$ & $\mathrm{K} 2 \mathrm{O}$ & P2O5 & LOI & Total \\
\hline $3 R-1,42-45$ & 15.02 & \multirow{21}{*}{$\left.\right|^{11-A}$} & \multirow[t]{9}{*}{1} & 47.7 & 12.9 & 5.11 & 2.6 & 12.5 & 0.219 & 2.96 & 4.59 & 3.24 & 0.14 & 7.55 & 99.5 \\
\hline $3 R-1,42-45(M n)$ & 15.03 & & & 44.4 & 11.1 & 6.04 & 3.3 & 13.4 & 4.150 & 3.20 & 3.78 & 2.66 & 0.14 & 8.03 & 100.2 \\
\hline $3 R-1,106-109$ & 15.66 & & & 47.7 & 15.6 & 3.82 & 2.4 & 10.1 & 0.899 & 1.36 & 4.63 & 3.17 & 0.59 & 10.08 & 100.3 \\
\hline $4 \mathrm{R}-1,0-3$ & 24.30 & & & 47.3 & 11.6 & 5.66 & 4.5 & 13.6 & 0.198 & 2.94 & 3.68 & 2.40 & 0.19 & 7.66 & 99.7 \\
\hline $4 \mathrm{R}-1,4-7$ & 24.34 & & & 49.1 & 12.0 & 4.45 & 3.4 & 13.5 & 0.213 & 3.00 & 3.88 & 3.18 & 0.17 & 7.90 & 100.8 \\
\hline $4 R-1,80-83$ & 25.10 & & & 47.5 & 12.2 & 5.72 & 3.0 & 13.9 & 0.720 & 3.34 & 4.13 & 3.03 & 0.14 & 7.45 & 101.1 \\
\hline $4 R-1,140-150$ & 25.70 & & & 41.0 & 10.0 & 8.20 & 8.6 & 10.3 & 0.090 & 2.75 & 2.95 & 1.71 & 0.24 & 13.40 & 99.2 \\
\hline $4 R-2,2-6$ & 25.82 & & & 35.2 & 5.5 & 11.30 & 16.1 & 9.3 & 0.163 & 1.16 & 1.47 & 0.83 & 1.02 & 17.90 & 99.9 \\
\hline $5 R-1,128-132$ & 34.98 & & & 47.2 & 10.8 & 12.60 & 3.0 & 12.7 & 0.216 & 2.83 & 3.08 & 1.34 & 0.33 & 6.97 & 101.1 \\
\hline $6 \mathrm{R}-1,36-40$ & 43.26 & & & 46.9 & 10.8 & 12.40 & 3.1 & 12.7 & 0.181 & 2.45 & 4.49 & 1.59 & 0.31 & 6.43 & 101.4 \\
\hline $7 R-1,95-97$ & 53.35 & & & 46.8 & 11.2 & 11.00 & 3.5 & 12.1 & 0.154 & 2.55 & 4.65 & 1.39 & 0.31 & 7.58 & 101.2 \\
\hline $8 R-2,132-136$ & 64.72 & & & 46.0 & 10.9 & 9.00 & 6.4 & 11.7 & 0.193 & 2.68 & 3.83 & 1.20 & 0.32 & 8.04 & 100.3 \\
\hline 10R-1, 4-5 (F) & 80.44 & & & 14.8 & 0.3 & 0.03 & 42.3 & 0.1 & 0.005 & 0.01 & 0.02 & 0.02 & 0.10 & 21.38 & 79.0 \\
\hline $13 \mathrm{R}-1,43-45$ & 108.73 & & \multirow[t]{3}{*}{5} & 52.5 & 12.5 & 2.95 & 4.4 & 7.9 & 1.860 & 0.62 & 3.55 & 2.37 & 0.60 & 9.10 & 98.4 \\
\hline 13R-1, 53-58 & 108.83 & & & 53.6 & 12.5 & 3.39 & 4.4 & 8.3 & 1.870 & 0.64 & 3.89 & 2.34 & 0.69 & 9.01 & 100.6 \\
\hline 13R-2, 30-32 & 109.18 & & & 53.1 & 12.6 & 3.36 & 4.6 & 7.7 & 1.830 & 0.74 & 3.70 & 2.61 & 0.61 & 9.26 & 100.1 \\
\hline $14 \mathrm{R}-2,23-26$ & 116.13 & & \multirow[t]{7}{*}{2} & 47.0 & 9.8 & 13.40 & 6.1 & 12.8 & 0.191 & 2.52 & 3.14 & 0.42 & 0.32 & 5.36 & 101.1 \\
\hline 16R-1, 30-33 & 131.41 & & & 46.1 & 9.9 & 10.30 & 6.4 & 12.3 & 0.200 & 2.87 & 3.99 & 0.61 & 0.34 & 7.36 & 100.4 \\
\hline $16 \mathrm{R}-1,30-33(\mathrm{~F})$ & 131.43 & & & 19.9 & 3.4 & 0.07 & 36.5 & 0.1 & 0.010 & 0.03 & 0.42 & 0.05 & 0.10 & 24.13 & 84.7 \\
\hline $17 \mathrm{R}-1,108-113$ & 141.48 & & & 44.8 & 10.1 & 9.16 & 6.7 & 13.0 & 0.265 & 3.39 & 3.88 & 0.58 & 0.33 & 6.48 & 98.7 \\
\hline $19 R-1,27-29$ & 159.37 & & & 45.0 & 11.4 & 7.36 & 5.7 & 11.9 & 0.239 & 2.08 & 5.26 & 0.85 & 0.38 & 8.10 & 98.3 \\
\hline 19R-2, 30-32 & 160.90 & $\mid 11-B$ & & 48.2 & 13.1 & 5.62 & 3.6 & 11.3 & 0.221 & 1.36 & 4.64 & 1.85 & 0.57 & 8.66 & 99.1 \\
\hline 19R-2, 67-72 & 161.27 & & & 46.8 & 10.1 & 10.10 & 7.5 & 11.8 & 0.205 & 2.50 & 4.07 & 1.06 & 0.37 & 6.61 & 101.1 \\
\hline $21 \mathrm{R}-1,70-74$ & 178.30 & & & 46.2 & 10.9 & 8.58 & 5.1 & 11.9 & 0.190 & 2.32 & 4.35 & 1.66 & 0.45 & 7.03 & 98.7 \\
\hline $22 \mathrm{R}-1,21-25$ & 187.21 & & & 46.6 & 10.1 & 11.00 & 5.5 & 11.1 & 0.186 & 2.63 & 3.70 & 1.13 & 0.39 & 6.05 & 98.4 \\
\hline $23 \mathrm{R}-1,14-17$ & 196.54 & & & 46.8 & 10.2 & 9.27 & 7.9 & 10.3 & 0.183 & 1.97 & 3.63 & 1.28 & 0.36 & 8.85 & 100.7 \\
\hline 25R-1, 49-52 & 216.19 & & & 44.8 & 9.6 & 4.67 & 4.1 & 17.5 & 0.213 & 2.03 & 3.02 & 3.15 & 0.37 & 9.24 & 98.7 \\
\hline $26 \mathrm{R}-1,120-124$ & 226.60 & & & 35.4 & 9.0 & 5.00 & 19.1 & 8.1 & 0.246 & 1.33 & 2.20 & 0.72 & 0.32 & 18.66 & 100.1 \\
\hline 26R-3, 52-55 & 228.92 & & & 29.6 & 6.8 & 3.92 & 25.5 & 6.2 & 0.404 & 0.98 & 1.10 & 0.40 & 0.33 & 24.43 & 99.7 \\
\hline $27 \mathrm{R}-2,128-131$ & 237.88 & IIII & & 20.0 & 4.4 & 3.46 & 34.7 & 4.2 & 0.225 & 0.70 & 0.19 & 0.10 & 0.27 & 30.40 & 98.6 \\
\hline 27R-5, 12-14 & 241.22 & & & 52.6 & 10.3 & 5.08 & 3.8 & 11.9 & 3.660 & 0.77 & 2.50 & 1.58 & 0.77 & 7.87 & 100.8 \\
\hline 27R-5, $123-126$ (dark) & 242.33 & & & 56.6 & 13.2 & 4.04 & 3.7 & 8.5 & 0.791 & 0.94 & 3.00 & 1.92 & 0.52 & 7.27 & 100.5 \\
\hline 27R-5, 123-126 (clear) & 242.35 & & & 30.8 & 6.9 & 2.28 & 26.5 & 5.1 & 0.299 & 0.65 & 1.12 & 0.55 & 0.36 & 24.62 & 99.2 \\
\hline
\end{tabular}

Note: $F^{*}$ : Thaumasite with $\mathrm{S}=4.8 \%$ and $\mathrm{C}=1.9 \%$; before calcination, sample gives a $36.81 \%$ weight loss at $110^{\circ} \mathrm{C}$

$802 \mathrm{~A}-4 \mathrm{R},-13 \mathrm{R},-25 \mathrm{R}$, and $-26 \mathrm{R})$ as they should be dioctahedral, and at $1.525-1.53 \AA$, even $1.54 \AA$ in the massive tuff where they appear as trioctahedral clay mineral such as saponite. Double peaks (060) often occur on diffractograms (i.e., samples from Core 802A-19R), suggesting a mixture of different smectites. Diffractograms from oriented untreated clay fractions also revealed two types of wellcrystallized smectites: in the uppermost massive tuff and in the pelagic clay layer (Cores $802 \mathrm{~A}-4 \mathrm{R},-13 \mathrm{R}$, and $-16 \mathrm{R}$ ) the main peak is at $15 \AA$, and in some horizon of the massive tuff the peak is at 13 $\AA$ (Core $802 \mathrm{~A}-6 \mathrm{R})$. Both types show identical patterns when glycolated $(17 \AA)$ and heated $(10 \AA)$. Low spacing $(12-13 \AA)$ is often characteristic of authigenic nontronite within lithified volcanosedimentary horizons or metalliferous deposits (Karpoff et al., 1980; Cole and Shaw, 1983; Karpoff, 1989).

SEM investigations with preliminary chemical microprobe tests allow the relationships and composition of these phases to be specified. In layers rich in pelagic components, ghosts of radiolarian tests appear fully argillized and filled by a Ca-K-zeolite of phillipsite type (Pl. 1, Fig. 1). The vesicles of volcanic glass show alteration rings as palagonite and subsequent coating by $\mathrm{Mg}$-smectite and rare zeolite (PI. 1, Fig. 2). In tuffaceous layers, intergranular phillipsite forms massive or as coalescent radiating bunches of crystals, as they are often described in hyaloclastites. Dodecahedra of analcime occur mainly within voids between volcaniclastic grains coated by clay minerals (Pl. 1, Fig. 3). Among small crystals of K-bearing analcime with two morphologies (dodecahedra and rhombs), an incongruous lone rod of Na-zeolite (natrolite?) exemplifies the complexity of diagenesis in such deposits (Pl. 1, Fig. 4).

\section{Fracture Fillings}

There are three types of veins based on the thickness and mineralogical composition (Fig. 3). The largest fissure veins, from $5 \mathrm{~mm}$ to several centimeters thick, and vug fillings (as occur in Core 802A-5R; Shipboard Scientific Party, 1990) are made of thaumasite $\left[\mathrm{Ca}_{3}\right.$ $\mathrm{Si}(\mathrm{OH})_{6} \mathrm{CO}_{3}, \mathrm{SO}_{4}, 12 \mathrm{H}_{2} \mathrm{O}$, well crystallized as compact fibers and rods (Pl. 2, Fig. 1). Chemical analysis of nearby pure thaumasite also establishes that the mineral is very poor in trace elements (Tables 3 and 4). Smaller fissures, $1-5 \mathrm{~mm}$ thick, are a combination of zeolites and thaumasite: (1) on the fracture walls, rhombs and cubes of Na-chabazite are well formed, and (2) in the fracture center occurs fine and acicular crystals of thaumasite (Pl. 2, Figs. 2 and 3). The intergrowth of zeolite and thaumasite shows a cogenetic formation from a single fluid (see also fig. 8, p. 181, in Shipboard Scientific Party, 1990). The thinnest fissures, less than a half-millimeter thick, are common in the fine-grained tuff and are coated by rhombs and cubs of a chabazite-type zeolite (Pl. 2, Fig. 4). XRD data specify the co-occurrence of herschelite (a Na-bearing variety of chabazite) and gmelinite (a Na-zeolite of the same crystallographical group as chabazite); a microprobe test gives a composition of these latter zeolites of about $57.3 \% \mathrm{SiO}_{2}, 21.5 \% \mathrm{Al}_{2} \mathrm{O}_{3}, 18.5 \% \mathrm{Na}_{2} \mathrm{O}$, and $2.5 \%$ $\mathrm{CaO}(\mathrm{Si} / \mathrm{Al}=2.35)$.

The location and abundance of the thaumasite crystallization through the tuff unit were estimated from the core photographs by the frequency of veins (number of subhorizontal white veins by recovered meter; Fig. 4). These white vein fillings were previously described, for lack of XRD determination, as microfibrous/platy zeolites or 
Table 4. Chemical composition of the bulk samples from Cenozoic tuff and nannofossil chalk, Site 802: trace elements (ppm).

\begin{tabular}{|c|c|c|c|c|c|c|c|c|c|c|c|c|}
\hline $\begin{array}{l}\text { Samples }(\mathrm{cm}): \\
\text { 129-802A. }\end{array}$ & $\begin{array}{l}\text { Depth } \\
\text { (mbsf) }\end{array}$ & Unit & $\begin{array}{l}\text { Mineral } \\
\text { Assoc. }\end{array}$ & $\mathrm{Sr}$ & $\mathrm{Ba}$ & v & $\mathrm{Ni}$ & Co & $\mathrm{Cu}$ & $\mathrm{Cr}$ & $\mathrm{Zn}$ & $\mathrm{Zr}$ \\
\hline $3 \mathrm{R}-1,42-45$ & 15.02 & \multirow{21}{*}{ II-A } & \multirow[t]{9}{*}{1} & 124 & 181 & 113 & 183 & 34 & 143 & 592 & 98 & 224 \\
\hline $3 R-1,42-45(M n)$ & 15.03 & & & 198 & 564 & 202 & 410 & 138 & 142 & 542 & 130 & 230 \\
\hline $3 R-1,106-109$ & 15.66 & & & 241 & 207 & 254 & 283 & 103 & 115 & 117 & 165 & 195 \\
\hline $4 \mathrm{R}-1,0-3$ & 24.30 & & & 185 & 140 & 188 & 225 & 49 & 89 & 557 & 120 & 235 \\
\hline $4 R-1,4-7$ & 24.34 & & & 121 & 128 & 135 & 232 & 53 & 89 & 582 & 110 & 229 \\
\hline $4 \mathrm{R}-1,80-83$ & 25.10 & & & 135 & 210 & 135 & 230 & 59 & 157 & 685 & 114 & 244 \\
\hline $4 R-1,140-150$ & 25.70 & & & 88 & 95 & 253 & 206 & 35 & 61 & 533 & 82 & 213 \\
\hline $4 R-2,2-6$ & 25.82 & & & 95 & 39 & 81 & 220 & 45 & 31 & 253 & 89 & 92 \\
\hline $5 R-1,128-132$ & 34.98 & & & 139 & 110 & 276 & 301 & 51 & 105 & 571 & 125 & 223 \\
\hline $6 \mathrm{R}-1,36-40$ & 43.26 & & \multirow[t]{4}{*}{2} & 78 & 120 & 228 & 295 & 48 & 117 & 605 & 119 & 194 \\
\hline $7 R-1,95-97$ & 53.35 & & & 86 & 126 & 259 & 282 & 48 & 109 & 653 & 139 & 194 \\
\hline $8 R-2,132-136$ & 64.72 & & & 290 & 124 & 272 & 266 & 50 & 144 & 544 & 112 & 203 \\
\hline 10R-1, 4-5 (F)* & 80.44 & & & 7 & 3 & 9 & 14 & 5 & 5 & 8 & 4 & 1 \\
\hline $13 R-1,43-45$ & 108.73 & & \multirow[t]{3}{*}{5} & 2092 & 213 & 67 & 217 & 117 & 225 & 55 & 150 & 143 \\
\hline 13R-1, 53-58 & 108.83 & & & 1587 & 255 & 68 & 232 & 139 & 122 & 43 & 137 & 143 \\
\hline 13R-2, 30-32 & 109.18 & & & 1881 & 221 & 77 & 222 & 132 & 192 & 78 & 122 & 143 \\
\hline $14 R-2,23-26$ & 116.13 & & \multirow[t]{7}{*}{2} & undosed & & & & & & & & \\
\hline $16 \mathrm{R}-1,30-33$ & 131.41 & & & 202 & 97 & 241 & 323 & 56 & 129 & 650 & 126 & 220 \\
\hline $16 \mathrm{R}-1,30-33(\mathrm{~F})$ & 131.43 & & & 93 & 2 & 41 & 17 & 5 & 8 & 7 & 10 & 3 \\
\hline $17 \mathrm{R}-1,108-113$ & 141.48 & & & 411 & 85 & 345 & 353 & 61 & 176 & 777 & 128 & 246 \\
\hline $19 \mathrm{R}-1,27-29$ & 159.37 & & & 163 & 71 & 151 & 856 & 51 & 351 & 243 & 121 & 210 \\
\hline 19R-2, 30-32 & 160.90 & \multirow{8}{*}{ 11-B } & & 204 & 105 & 174 & 221 & 44 & 124 & 125 & 143 & 192 \\
\hline 19R-2, $67-72$ & 161.27 & & & 132 & 151 & 234 & 280 & 35 & 91 & 557 & 102 & 177 \\
\hline $21 \mathrm{R}-1,70-74$ & 178.30 & & \multirow[t]{5}{*}{3} & 162 & 106 & 192 & 250 & 25 & 87 & 288 & 108 & 200 \\
\hline $22 \mathrm{R}-1,21-25$ & 187.21 & & & 198 & 71 & 245 & 281 & 34 & 175 & 714 & 110 & 191 \\
\hline 23R-1, 14-17 & 196.54 & & & 208 & 98 & 173 & 267 & 28 & 119 & 384 & 95 & 139 \\
\hline 25R-1, 49-52 & 216.19 & & & 195 & 78 & 618 & 74 & 24 & 1042 & 402 & 123 & 168 \\
\hline $26 \mathrm{R}-1,120-124$ & 226.60 & & & 485 & 169 & 121 & 139 & 21 & 55 & 171 & 112 & 101 \\
\hline $26 \mathrm{R}-3,52-55$ & 228.92 & & \multirow[t]{5}{*}{4} & 720 & 85 & 70 & 106 & 20 & 46 & 110 & 97 & 90 \\
\hline $27 \mathrm{R}-2,128-131$ & 237.88 & \multirow{4}{*}{ III } & & 884 & 53 & 72 & 102 & 14 & 32 & 119 & 55 & 55 \\
\hline 27R-5, $12-14$ & 241.22 & & & 395 & 732 & 95 & 190 & 39 & 431 & 31 & 181 & 162 \\
\hline 27R-5, 123-126 (dark) & 242.33 & & & 852 & 166 & 83 & 204 & 30 & 278 & 41 & 145 & 206 \\
\hline 27R-5, 123-126 (clear) & 242.35 & & & 871 & 91 & 47 & 219 & 16 & 44 & 58 & 103 & 108 \\
\hline
\end{tabular}

acicular anhydrite in the core description forms (Lancelot, Larson, et al.. 1990). The first occurrence of zeolite-thaumasitic veins is noticed at top of Core $802 \mathrm{~A}-6 \mathrm{R}$, at $42.9 \mathrm{mbsf}$, and the last occurrence (a rounded large thaumasite piece) is at the top of Core $802 \mathrm{~A}-20 \mathrm{R}$, at $168.3 \mathrm{mbsf}$. This interval is that of the analcime-rich tuff which is also that of the massive and compacted tuff, such as a welded tuff, with the lower porosities and the higher bulk densities (Shipboard Scientific Party, 1990).

\section{Secondary Mineral Associations}

Several mineralogical assemblages are defined, from top to bottom in Unit II, and are distinguished between more pelagic and massive tuff intervals (Table 2; Fig. 5).

1. Phillipsite-smectites-calcite-clinoptilolite. This assemblage, with the highest phillipsite contents, is characteristic of the uppermost section of yellowish palagonitic volcaniclastic claystone with Mn-oxide; recrystallized secondary calcite and higher smectite contents occur in the lower part of this interval with a mixture of phillipsite and clinoptilolite.

2. Analcime-smectites-phillipsite. This assemblage is that of the massive tuff (Cores 802A-6R to-12R, and -14R to -20R) with the chabazite and/or thaumasite veins. Phillipsite contents are low. The smectites are mainly trioctahedral. The transition with the underlying mineral association (3) appears gradational.

3. Phillipsite-smectites-analcime. This assemblage, associated with primary biogenic calcite, (from Core 802A-21R to the top of Core 802A-26R) marks the appearance of the analcime in the phillipsite-rich, calcareous tuffaceous claystone.

4. Smectites-clinoptilolite-phillipsite, with biogenic calcite. The lowermost section of Core 802A-26R, near the basal contact with the underlying chalk (Unit III), is differentiated from the deposits above by their clinoptilolite contents, and by the presence of primary calcite and quartz. The smectites are mainly dioctahedral. This assemblage remains through Unit III.

5. Clinoptilolite-smectites. The brown pelagic clay interval (Core $802 \mathrm{~A}-13 \mathrm{R}$ ) within the massive tuff is characterized by high clinoptilolite content. Little phillipsite and quartz occur at the top and bottom of this horizon.

\section{This classification emphasizes the following main observations:}

1. Phillipsite occurs in the whole sequence and prevails in the uppermost deposits where a secondary paragenesis appears as: smectites $\rightarrow$ phillipsite $\rightarrow$ clinoptilolite $\rightarrow$ calcite $\rightarrow$ oxides.

2. Clinoptilolite appears typical of the more pelagic beds.

3. Clinoptilolite and analcime never coexist.

4. Analcime is characteristic of the massive tuff with thaumasitic fissure veins, and the secondary mineral sequence in cemented tuff intervals is: smectites $\rightarrow$ phillipsite $\rightarrow$ analcime $\rightarrow$ chabazite-herschelite $\rightarrow$ thaumasite. This sequence of $\mathrm{Mg}-, \mathrm{K}-, \mathrm{Na}-$, and Ca-silicates is related to intense reactions between volcaniclastic deposits and pore fluids. At the beginning of the reaction, highly reactive silica could be provided by biogenic phases trapped in the redeposited tuff or by more silicic volcanic glass. The high measured chlorinity of interstitial waters is related to the uptake of water by highly hydrated neoformed silicates (France-Lanord et al., 1991, and this volume).

The zeolites-thaumasite suite of the tuff Unit II from Site 802 has to be compared to the known oceanic occurrences of such minerals in order to evaluate the possible conditions of the water-rock interactions and the factors determining these intense diagenetic reactions (see below). 


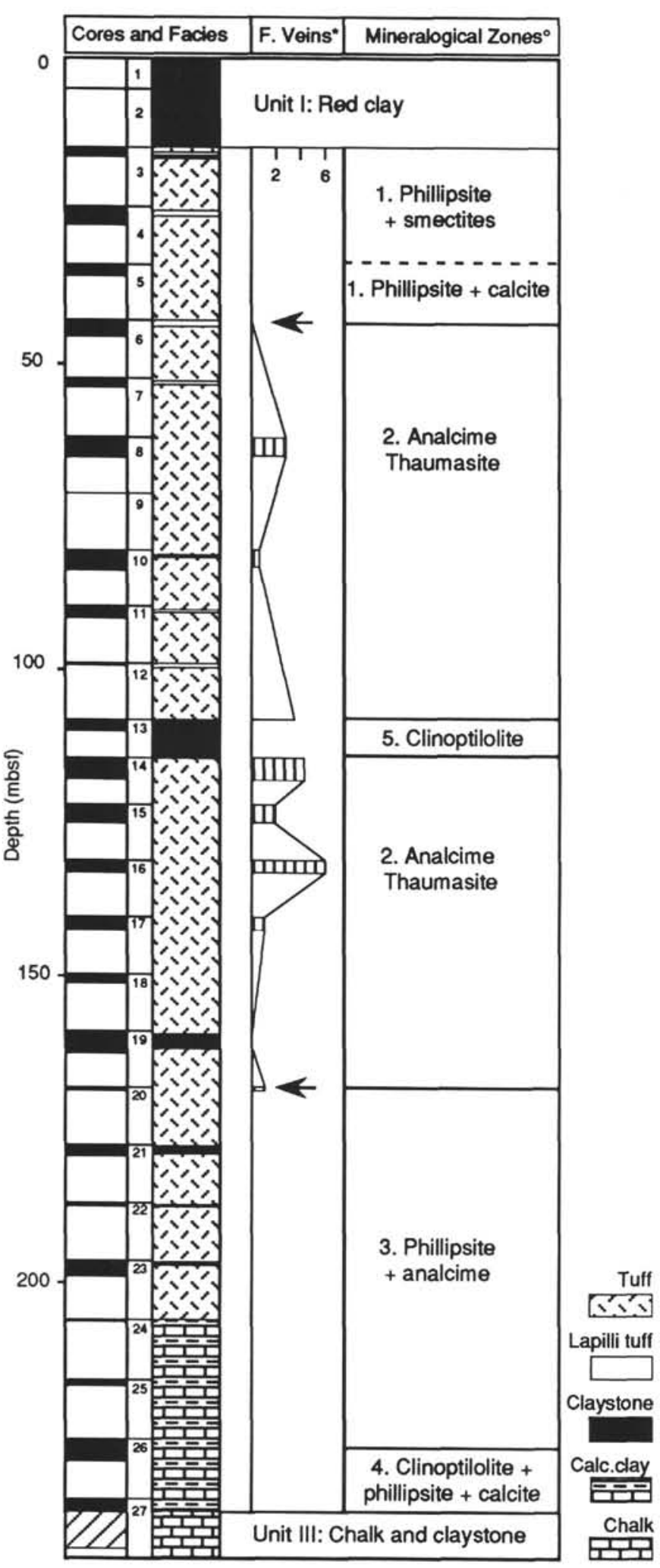

Figure 4. Secondary mineralogical assemblages through tuff Unit II at Site 802. Core recovery and facies are shown on the left. Central column ("F. Veins*"): frequency of thaumasite veins estimated as number of fractures by recovered meters. Arrows: first and last occurrences of thaumasite. Right column: distribution of the five typical assemblages cited with prevalent secondary minerals (see text).

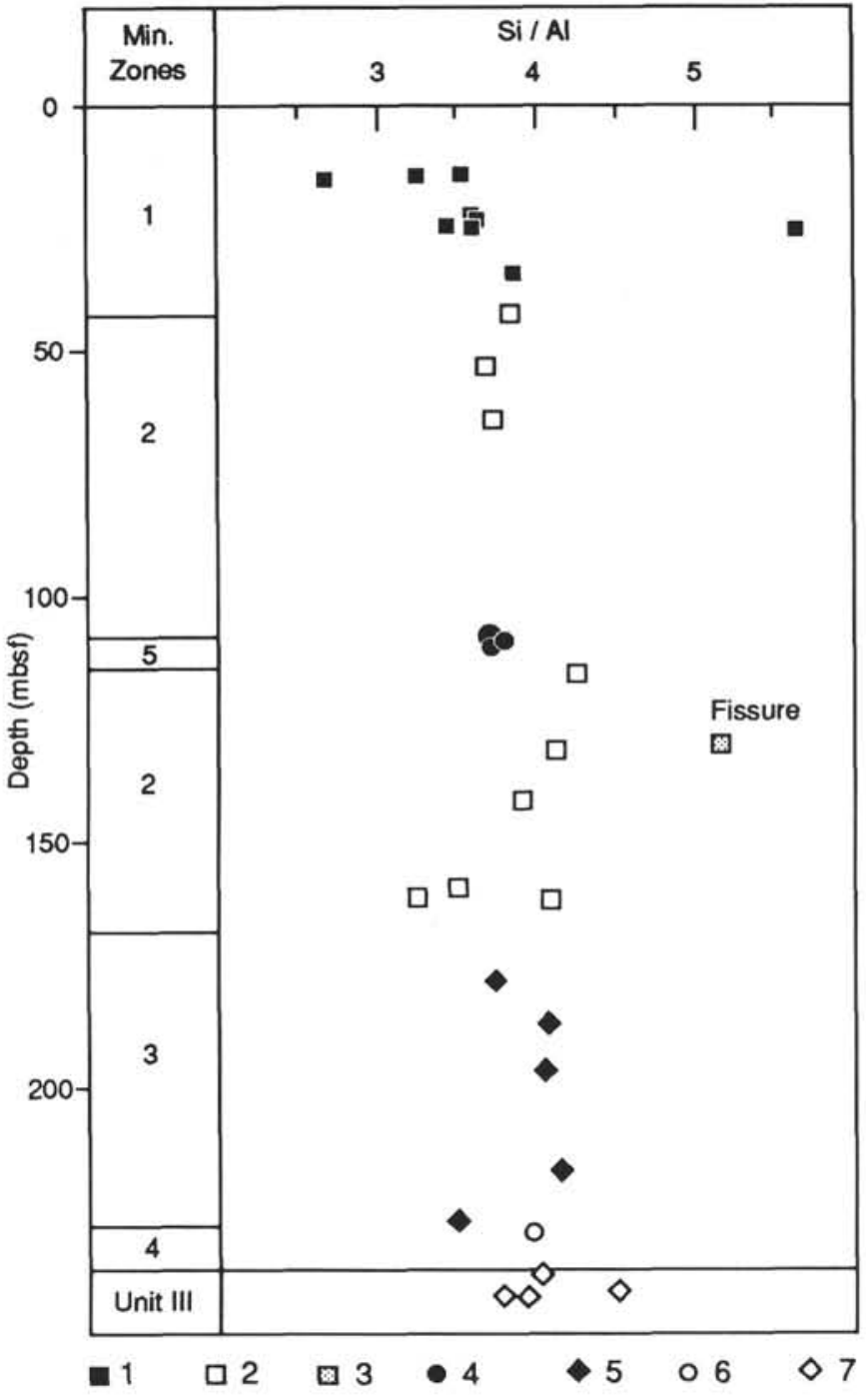

Figure 5. Si/Al ratio vs. depth in tuff Unit II at Site 802 . The five mineralogical zones are described in the text (Fig. 4). Key to sample symbols: $1=$ tuff with phillipsite-smectites; $2=$ tuff with analcime-thaumasite; $3=$ thaumasite and zeolite veins; 4 = pelagic clay with clinoptilolite; 5 = tuff with phillipsite-analcime; $6=$ tuffaceous calcareous claystone with clinoptilolite-smectites; $7=$ chalk and claystone with clinoptilolite-smectites (Unit III).

\section{CHEMICAL TRENDS}

The bulk chemical compositions of Unit II and uppermost section of Unit III samples (Tables 3 and 4) are consistent with the mineralogical composition and follow the zonation described earlier. These compositions are related to the both pelagic and volcaniclastic input and later diagenesis.

The $\mathrm{Si} / \mathrm{Al}$ ratio is fairly constant with depth (Fig. 5). It is high (about $3.5-4)$ relative to the $\mathrm{Si} / \mathrm{Al}$ ratios of typical volcanogenic components (basalt $\approx 2.7-2.9 ;$ trachyte $\approx 3.2$ ). This high ratio probably relates a significant siliceous biogenic contribution and/or the original composition of the volcaniclasts. Then, the abundant silicate authigenesis of the Miocene tuff appear to have been controlled by a high silica activity during water-rock diagenetic reactions.

The presence of primary volcanic phases is expressed by the high and well-correlated Ti, Zr, and Cr contents (Fig. 6). The high Ti contents of the volcaniclastic deposits, in comparison to that for oceanic basalts, may be related to the $\mathrm{Ca}$ depletion $(\mathrm{CaO}<10 \%$ in the massive tuff) which resulted 

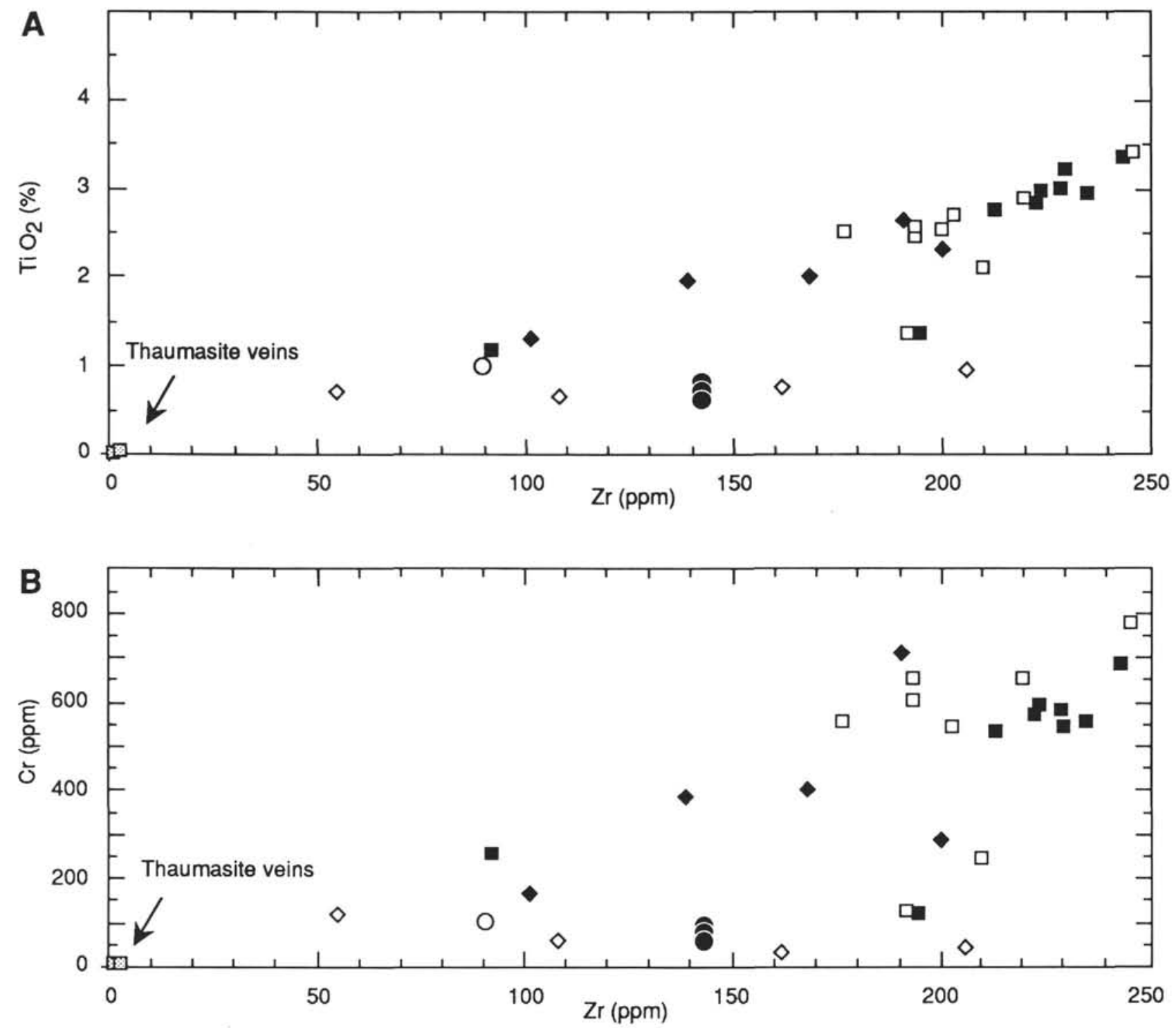

Figure 6. A. $\mathrm{Zr}$ vs. $\mathrm{TiO}_{2}$. B. $\mathrm{Zr}$ vs. $\mathrm{Cr}$ in Unit II and top of Unit III at Site 802 . Symbols are as in Figure 5.

from intense alteration. The released $\mathrm{Ca}$ from volcaniclasts is also reflected in the high $\mathrm{Ca}$ content of pore fluids. Magnesium contents vs. depth also reflect the volcanogenic and biopelagic influences on the deposits (Fig. 7). The ratio $\mathrm{Mg} /(\mathrm{Mg}+\mathrm{Fe}$ ) displays similar variations. Magnesium and iron are used first for the formation of authigenic clay minerals. The low $\mathrm{Ti} /(\mathrm{Ti}+\mathrm{Fe}+\mathrm{Mn})$ ratios could be used as an index of the oxidative alteration which ended the secondary fixation of $\mathrm{Fe}-\mathrm{Mn}$ oxides (with the correlative fixation of trace metals such as $\mathrm{Ni}$, $\mathrm{Co}$, and $\mathrm{Cu}$ ); this trend is well recorded in the uppermost section of the Unit II and in the more pelagic intervals (Fig. 7). The differential zeolitization of the section, with $\mathrm{K}$-phillipsite to $\mathrm{Na}-\mathrm{Ca}$ zeolites, is recorded by $\mathrm{K} /(\mathrm{Na}+\mathrm{Ca}$ ) ratio (Fig. 7); a part of the total $\mathrm{Na}$ could be adsorbed by pelagic clay (i.e., as drying-induced halite) and $\mathrm{Ca}$ is also taken during calcite formation.

The calcium-strontium relationship (Fig. 8) reflects diagenesis that affects the biogenic phases (release of $\mathrm{Sr}$ during dissolution-recrystallization) and that makes the condensed deposits enable to fix $\mathrm{Ca}$ and $\mathrm{Sr}$ in authigenic silicates and oxides. The basal sequence of Unit II and the chalk from Unit III have a Sr/Ca ratio equal to that of the calcareous biogenic deposits. The intergranular secondary calcite in the uppermost section of Unit III (Core 802A-4R) is nearly Sr-free. The clinoptilolite-rich clay interval (Core 802A-13R) has the highest
Sr content, probably released from the over- and underlying highly altered tuff which volcanic phases also are a source of $\mathrm{Sr}$; in this deposit the strontium of the pore fluids kept a low isotopic signature of basaltic glass (France-Lanord et al., this volume).

The sulfur isotopic data obtained from Site 802 thaumasite samples are similar to those of the interstitial water in adjacent samples, and essentially close to that of seawater, suggesting very little S-isotopic fractionation during the formation of thaumasite (Alt and Burdett, this volume).

The successive stages of deposition of sediments also are reflected in the bulk chemical compositions. At the base of the sequence (Subunit IIB, from Cores 802A-26R to Section 802A-19R-2) volcaniclasts are mixed with reworked calcareous deposits; above this interval, the volcaniclastic discharge (from the top of Core $802 \mathrm{~A}-19 \mathrm{R}$ to $-14 \mathrm{R}$ ) stops, giving way to a slowly deposited clinoptilolite-rich clay horizon which condensed $\mathrm{Fe}, \mathrm{Mn}, \mathrm{Ni}, \mathrm{Co}, \mathrm{Cu}$, and $\mathrm{Sr}$ (Core 802-13R). Subsequent volcanic deposit (from Cores 802A$12 \mathrm{R}$ to the top of Core $802 \mathrm{~A}-3 \mathrm{R}$ ) shows two types of transformations: at the base, alteration is similar to that of the underlying tuff with $\mathrm{Na}-\mathrm{Ca}$-zeolites and thaumasite, while on the top a more typical facies (with palagonite, phillipsite, and oxides) from seawater oxidative alteration prevails. 


\section{SECONDARY MINERALS AND INTERSTITIAL WATERS OF THE TUFF: COMPARISON WITH OTHERS OCCURRENCES}

\section{Zeolites and Thaumasite}

The zeolitization of volcaniclastic deposits and basalt in the marine and continental realms is the subject of numerous studies, syntheses, and compilations of works (e.g., Mumpton, 1977; Sand and Mumpton,1978; Kastner, 1981; Gottardi and Galli, 1985). During the early low temperature alteration of basalt and volcanic glass, following several steps of dissolution-precipitation, zeolite minerals form generally after palagonite and clay minerals (references in Kastner, 1976; Honnorez, 1981; Crovisier et al., 1987). Reactions are facilitated in a highly saline alkaline environment than in seawater (references in Kastner, 1981). Early diagenesis favored by very low sedimentation rates results in a zeolitic red clay facies or in volcanosedimentary indurated layers, both related to volcanic and/or oceanographic events (Petzing and Chester, 1979; Karpoff, 1980; references in Karpoff, 1989). In continental volcaniclastic sequences, as in oceanic crust, metamorphic processes conduce to a zeolite zonation related to depth, temperature, and composition of interacting waters (Iijima and Utada, 1966; Sheppard and Gude, 1969; Wood et al., 1976; Moncure et al., 1981; Malley et al., 1983; Alt et al., 1986).

Phillipsite and clinoptilolite, common diagenetic minerals in deep-sea sediments, are formed by an interaction between glass, biogenic silica and seawater. Clinoptilolite formation requires a high $\mathrm{Si} / \mathrm{Al}$ ratio of the reactive compounds, as a higher silica activity during reactions. It is frequently suggested that clinoptilolite forms from phillipsite. The frequencies of the clinoptilolite vs. phillipsite are related to the nature of the fluid and the glass, and to time. Phillipsite forms faster in saline alkaline lake deposits from rhyolitic glass; in marine conditions clinoptilolite forms easier from silicic glasses and in siliceous deposits, and phillipsite forms preferentially from basaltic glass. In oceanic sediments, phillipsite and clinoptilolite occurrences are related to age and depth, as a result of diagenetic reactions; clinoptilolite is more common in older (pre-Oligocene), deeper sequences. The temperatures of stability of phillipsite and clinoptilolite range respectively from $0^{\circ} \mathrm{C}$ to $80^{\circ} \mathrm{C}$ and from $0^{\circ} \mathrm{C}$ to $150^{\circ}-200^{\circ} \mathrm{C}$ (from above references).

Analcime is less common in oceanic sediments than are phillipsite and clinoptilolite; it is very common in saline alkaline lake deposits. Analcime also characterizes a low-grade burial metamorphism. Its temperature of stability ranges from $0^{\circ} \mathrm{C}$ to $200^{\circ} \mathrm{C}$. The formation of analcime is more often attributed to the transformation of a zeolite precursor, mainly clinoptilolite. This transformation requires a supply in $\mathrm{Na}$ and releases $\mathrm{Si}$ and $\mathrm{Ca}$. The reactions are enhanced by heating (e.g., Sheppard and Gude, 1969; Walton, 1975; Moncure et al., 1981; Wirsching, 1981). The appearance of analcime is also related to depth in the sedimentary section. Analcimization conditions are presumed to occur around $150^{\circ}-$ $160^{\circ} \mathrm{C}$ at $\mathrm{pH} 9$ and at slightly higher temperature at $\mathrm{pH} 8$ (Abe and Aoki, 1976). Analcime was observed in the basal sediments from DSDP Site 456, which were transformed by baking at contact with basalt (Desprairies and Jehanno, 1983). In subaerial tuffs the $\mathrm{Na}$ supply is often attributed to intruding seawater (i.e., Iijima and Harada, 1969). Besse et al. (1981) described analcime in pyroclastic deposits from the Indian Ocean, where the analcime occurrence correlates with an increasing salinity of the interstitial waters. Hydrothermal metamorphism $\left(>50^{\circ}\right.$ to $250^{\circ} \mathrm{C}$ ) is cited as the cause of analcime formation in recent volcaniclastic deposits from the Lau and Fiji Basins (von Rad et al., 1990).

Chabazite, plus herschelite and gmelinite ( $\mathrm{Ca}$ to $\mathrm{Na}$ species) occurrences are often related to low-temperature hydrothermalism and lower grade metamorphism than that which generates analcime (Wood et al., 1976). Common in sediments, chabazite is also a frequent phase in tuffaceous deposits in saline lakes; intergrowths with gmelinite are common (Gottardi and Galli, 1985, and references therein). Its forms below $80^{\circ} \mathrm{C}$.

Thaumasite, $\mathrm{Ca}_{3} \mathrm{Si}(\mathrm{OH})_{6} \mathrm{CO}_{3} \mathrm{SO}_{4}, 12 \mathrm{H}_{2} \mathrm{O}$, is a white, fibrous, hexagonal silicate with a six-fold coordination of silicon. This mineral form a solid solution with ettringite (Al) and jouravskite (Mn). The US GEOREF literature database contains only 66 titles in mineralogical and geological citations about this mineral; some references could be added by cross-checking the citations. From the first description (Nordenskjöld, 1878) and into the 1970s, works on thaumasite were focused on its crystal structure characterization, which was fixed by Lafaille and Protas (1970), Edge and Taylor (1971), and refined by Effenberger et al. (1983). The geological environments of the samples used for crystallographical studies are often poorly described. Vogt (1938) and Knill (1960) made the earliest compilations of thaumasite occurrences with descriptions of the paragenetic minerals. Thaumasite is described in several environments, but no reference for the deep-sea realm was found.

1. Thaumasite is formed in nongeological environments: in furnace slags, cements, and roads materials, as a product of the interaction between waters and calcium and sulfur-rich compounds (i.e., Wilson, 1978; Hunter, 1988).

2. In the U.S. and northern Europe, thaumasite is found in sulfur and ore deposits and in old metamorphic rocks (metadolerites and skarns), and as vug veins and fracture fillings (Vogt, 1938; Knill, 1960; Badalov and Turesebekov, 1968; Chukhrov, 1972). Associated minerals include heulandite, analcime, laumonite, chabazite, chlorite, apophyllite, barite, gypsum, and anhydrite. Thaumasite always forms during the last stage of mineralization after zeolitization; the cited conditions of formation are related to weathering or percolation of fluids in a hypogene environment.

3. In old basalts and pyrometamorphic facies (Europe), thaumasite is described in vesicles and fissures, associated with zeolites, apophyllite, calcite, and gypsum (Paulitsch, 1973; Hentschel, 1979; Postl and Walter, 1983).

4. The rare descriptions of thaumasite in rocks quite similar to the Miocene tuff from Site 802 are as fissure veins in tuff from a caldera in Italy (Federico, 1970), and in a drill hole in Mururoa atoll (Noack, 1983). In the latter case, the environment of thaumasite is that of the submarine volcanic breccias forming the volcanic island; the water depth of the setting of lavas and breccias is not given, as it should be shallow. At about $550 \mathrm{~m}$ below the surface of the drill hole, thaumasite is cementing masses in a few samples. Associated minerals in others cracks include analcime, gyrolite, gmelinite, chabazite, phillipsite, and apophyllite. Thaumasite is believed to be the last product of alteration during the seawater-basalt interaction.

Giampaolo (1986) concluded from thermal properties of a thaumasite specimen that "at atmospheric pressure, the kinetic cut-off temperature, i.e., the temperature at which no dehydration occurs in geologically significant times so that thaumasite can be considered a phase indefinitely stable, has been established to be $60^{\circ} \pm 5^{\circ} \mathrm{C}$." At higher temperatures thaumasite decomposes to calcite and gypsum. Giampaolo (1986) also suggests that thaumasite could be considered as "an index mineral of low-enthalpy geothermics."

\section{Interstitial Waters}

Pore-fluid compositions from the Site 802 tuff have only a few equivalents in the DSDP-ODP record (France-Lanord et al., this volume). In the northwest Pacific Ocean, such modified fluids with high chlorinity and high $\mathrm{Ca}$ content, and with low $\mathrm{Mg}, \mathrm{Na}$, and $\mathrm{K}$ contents, were recently observed in Sites 792, 793, 832, 833, and 841 .

The ages, petrographical and sedimentological characteristics, and diagenetic facies of the deposits drilled at these sites also are very similar to that of the Site 802 . 


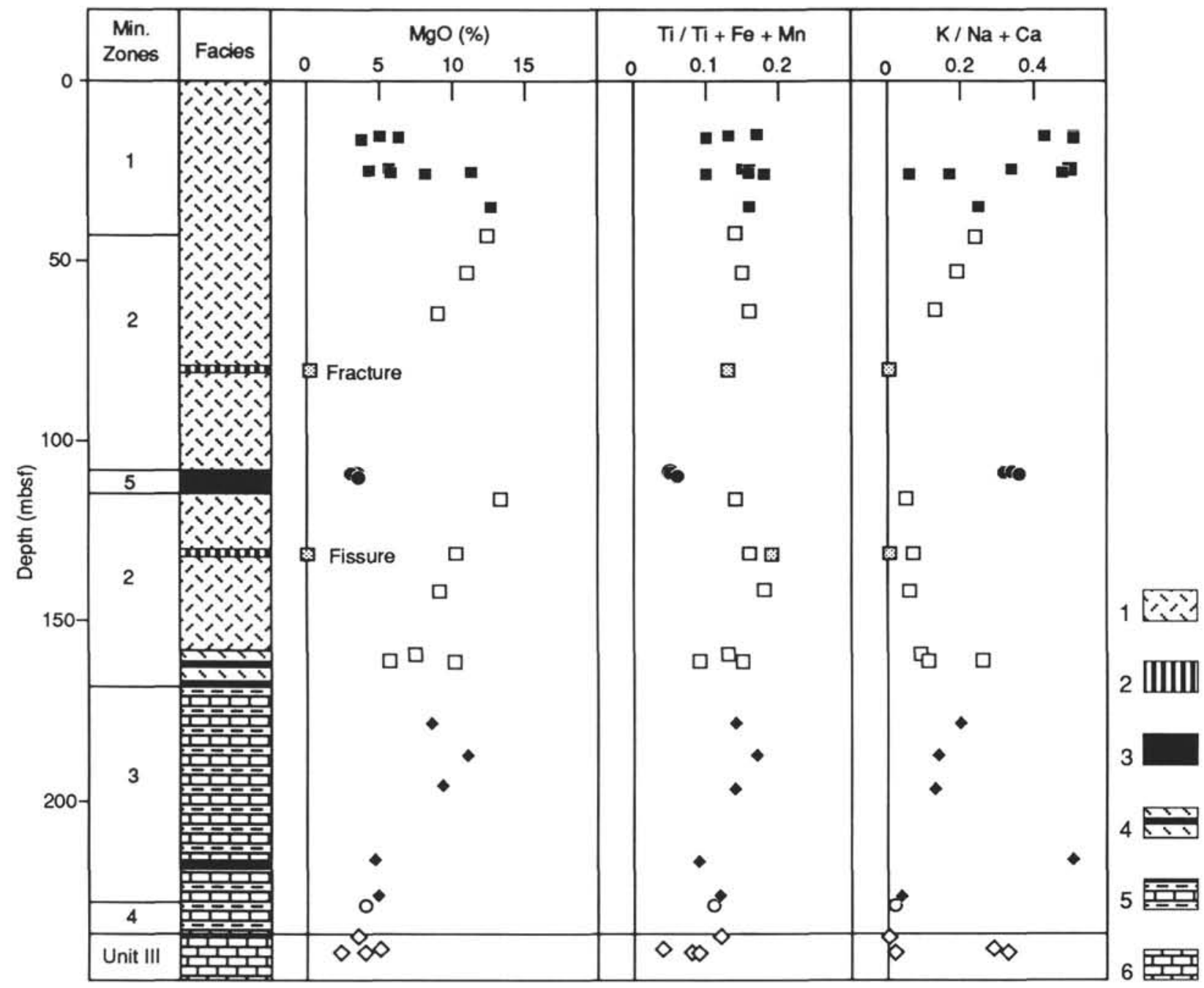

Figure 7. Variation in $\mathrm{MgO} . \mathrm{Ti} /(\mathrm{Ti}+\mathrm{Fe}+\mathrm{Mn})$, and $\mathrm{K} /(\mathrm{Ca}+\mathrm{Na})$ vs. depth in Unit II and top of Unit III at Site 802. Symbols are as in Figure 5. Lithologic symbols: 1 = tuff; 2 = thaumasite and zeolite veins; 3 = pelagic clay; $4=$ tuff with claystone; $5=$ tuffaceous calcareous claystone; $6=$ chalk and clayey chalk.

1. Sites 792 and 793 (Leg 126, $1787 \mathrm{~m}$ and $2975 \mathrm{~m}$ water depths), located in the Izu-Bonin Basin, about $70 \mathrm{~km}$ of the volcanic front between volcanic islands, recovered upper Oligocene to Pliocene vitric silty claystone and sandstone with basalt, andesite, dacite clasts, and pumice; the common secondary minerals from alteration of volcanogenic phases are abundant smectites and clinoptilolite; analcime is found in several deep horizons with chabazite (at Site 783) or with wairakite (Site 792), and is associated with gypsum which forms veins or nodules (Taylor, Fujioka, et al., 1990).

2. Sites 832 and 833 (Leg 134, $3089 \mathrm{~m}$ and $2629 \mathrm{~m}$ water depths) are located in central part of the north Aoba Basin at about $72 \mathrm{~km}$ from an active volcano and at about $24 \mathrm{~km}$ of volcanic islands. The water-profile anomalies of Pliocene-Miocene well-cemented volcanic sandstone and basaltic breccia are attributed to precipitation of authigenic carbonate and phosphate minerals. A very high sedimentation rate of $313 \mathrm{~m} / \mathrm{m}$.y. was calculated for a sequence of black volcanic sand and fine-grained basaltic breccia at Site 833 (Collot, Greene, Stokking, et al., 1992).

3. Site 841 (Leg 135, $4800 \mathrm{~m}$ water depth) near the Tonga Trench, drilled a thick Miocene volcaniclastic turbidites and Eocene dacitic welded tuff. The secondary minerals comprise smectites, zeolites and thaumasite (Parson, Hawkins, Allan, et al., 1992; Schöps, pers. comm., 1991).
All these sites have identical characteristics: (1) they are located in forearc and intra-arc basins, close to volcanic island or seamount, or to active volcano; (2) the volcanogenic sequences are young and reported to Oligocene-Miocene volcanic events; (3) the accumulation rates of tuff or basaltic breccia sequences are very high; (4) the alteration and diagenetic evolution of the volcanogenic deposits is well developed and resulted in evolved $\mathrm{Ca}$-Cl-rich pore waters and authigenic $\mathrm{Ca}$ - and $\mathrm{Na}$-rich zeolites, $\mathrm{Ca}$-carbonates, or Ca-sulfates. In nearby arc sites, the volcaniclastic deposits contain sometimes rhyolitic glasses.

The second, third, and fourth characteristics also are that of the deepest Site 802 deposits.

\section{DISCUSSION AND CONCLUSION}

\section{Mineralogical and Geochemical Evolution of the Miocene Tuff}

From the mineralogical and geochemical data obtained on the Miocene tuff at Site 802, and the known conditions of mineral genesis, the diagenetic evolution of the deposits can be evaluated. A simplified reaction sequence, involving at least three steps, could be proposed as follows: 


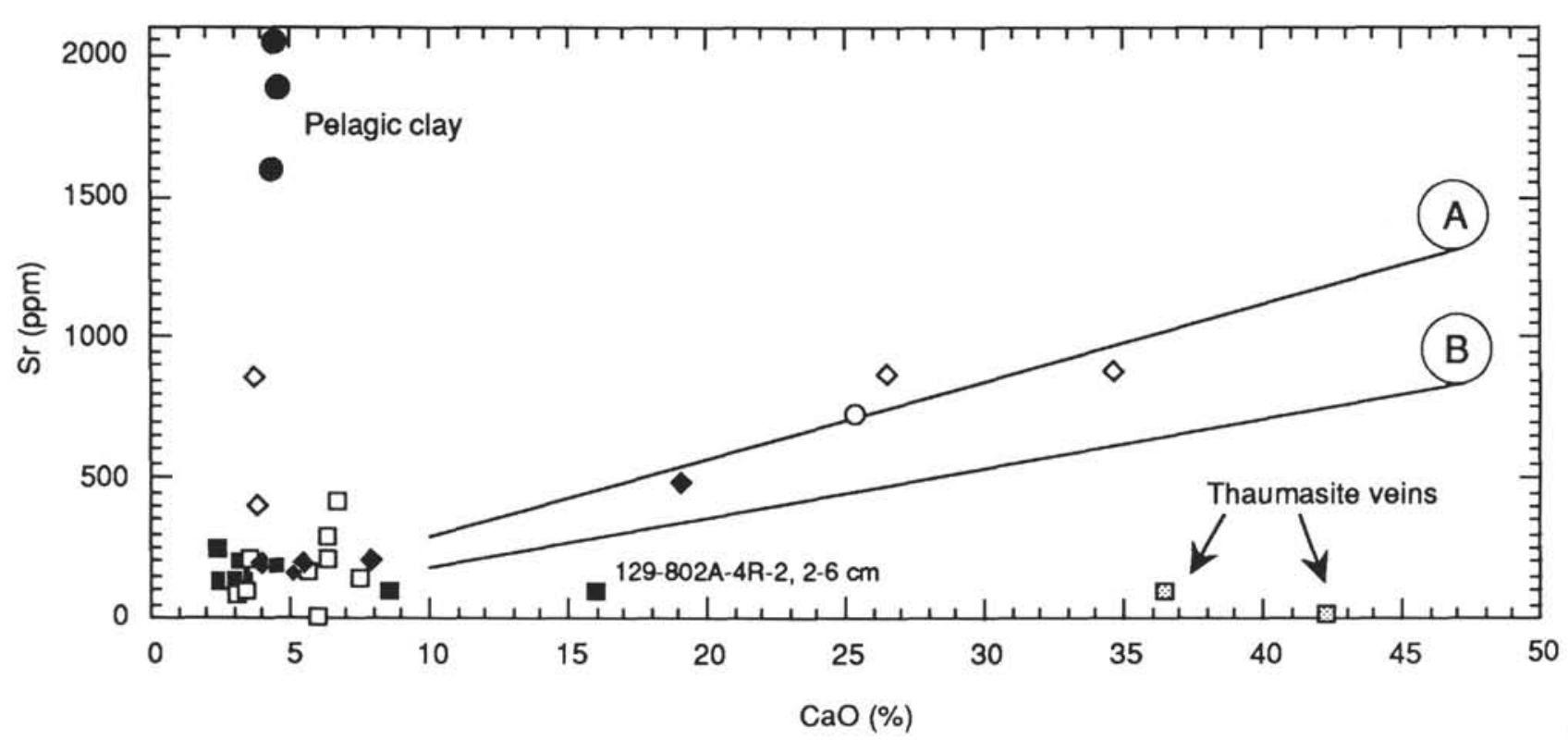

Figure 8. Cross plot of $\mathrm{CaO}$ vs. Sr in Unit II and top of Unit III at Site 802. Same symbols as in Figure 5. A. Sr/Ca relationship in recent surface sediments (after Baker et al., 1982); B. Sr/Ca relationship in Miocene calcareous oozes (after Graham et al., 1982).

1. Low-temperature alteration of the primary phases of the tuff $\left(0^{\circ}-50^{\circ} \mathrm{C}\right)$ :

Glass + seawater $\rightarrow$ smectites + phillipsite
Glass + biogenic phases + seawater $\rightarrow$ smectites + clinoptilolite

2. Higher temperature alteration of the tuff $\left(>50^{\circ} \mathrm{C}\right.$ to about $\left.150^{\circ} \mathrm{C}\right)$ :

Clinoptilolite + glass + seawater $\rightarrow$ analcime + water $+\mathrm{Si}, \mathrm{Ca}, \mathrm{Na}$

3. Cooler temperature authigenesis in the fissure veins $\left(<60^{\circ} \mathrm{C}\right)$ : Water $+(\mathrm{Si}, \mathrm{Ca}, \mathrm{Na}) \rightarrow$ chabazite + herschelite + thaumasite $\rightarrow$ evolved pore fluids

The roles of temperature, $P \mathrm{H}_{2} \mathrm{O}, P \mathrm{PC}_{2}$ still remain to be specified. The possible temperature gradient appears better related in this case to interaction of heated glass and basaltic fragments with normal seawater, which was consequently temporarily heated. These sequential reactions resulted in the highly lithified facies where the last stage of fluid circulation was manifest by thaumasite veins. The rate of such alteration-authigenesis processes overprint the influence of the diffusion of seawater, which is now indicated by oxidized brownish facies only near the seafloor interface.

Consequently the main factor determining the water-rock reactions that ended in the formation of thaumasite veins is the depositional style: massive, dense discharge of reworked, polyphased volcanogenic compounds in a deep basin. Evidence of the tectonicvolcanic stages of the source is provided by the sequential sedimentary facies at Site 802: (1) calcareous deposits and chalk with shallow-water debris as indexes of the disaggregation of deposits around a volcanic island, (2) mixed calcareous and low-temperature altered volcaniclasts, (3) massive volcaniclastic deposits as mass flows, with coarsening- and thickening-upward trend, resulting from the most intense volcanic activity. The rapid intrusion into the basin of the latter discharges which include a variable mixture of epiclasts, subaerial, and submarine new glasses, should have provided a sufficient temperature gradient between rock fragments and seawater to induce analcimization. Progressive cooling of the resulting solutions, which were $\mathrm{Si}$ and $\mathrm{Ca}$-enriched, then formed the latest veins of $\mathrm{Ca}$-zeolite and thaumasite. The high chloride concentration of the residual pore fluids results from the highly hydrated minerals formation. Such an "internal low-grade hydrothermalism" appears confined to the more volcaniclastic and massive beds with higher accumulation rates, as this analcime-thaumasite section is bordered below and above by more classical low-temperature smectite-zeolite diagenetic sequences. The early stage of the compaction and lithification, also expressed by fluid-escape and microfaulting sedimentary structures, must have played an important role in the formation of the numerous, large, horizontal thaumasite veins.

\section{Origin of the Miocene Tuff in the Central Mariana Basin}

The problem of the volcanic source of the massive tuff found at Site 802 was debated during Leg 129. On the basis of the estimated age of volcanism and the fact that no volcanic edifice is close to Site 802 on the most recent bathymetric charts (which was one reason for the choice of this drill site position), this source was first presumed to have been island or seamount of the Caroline Ridge as far as $350 \mathrm{~km}$ to the south (Lancelot, Larson, et al., 1990). Nevertheless, the results of this study bring on a new subject for discussion about the proximity of the volcanic source. Indeed, all the other known sites which are comparable with Site 802 , in terms of the (1) age of volcanism, (2) petrological and sedimentological type of tuffaceous deposits, (3) thickness and related high sedimentation rate, (4) degree of alteration, (5) complex secondary mineral assemblages with analcime, calcium carbonates or sulfates, and thaumasite, and (6) unusual pore-fluid composition, are sites located no farther than $80 \mathrm{~km}$ from seamount or active volcanic island. The water depths of these sites (Sites 792, $793,832,833$, and 841 ) range from 1787 to $4800 \mathrm{~m}$. We hypothesize that the thaumasitic tuff at deep-water Site 802 is most likely derived from a nearby edifice, and that this unmapped edifice is now, or once was, located in a small radius $(\approx 100-150 \mathrm{~km})$ around the site. The confirmation of the presence of such a volcanic edifice could be the subject for future geological and bathymetric investigations.

\section{Conclusion}

The Miocene thaumasitic tuff at Site 802, located in the deepest area of the Mariana Basin reveals new basic aspects of the seawater- 
basalt interactions depending upon the type and mechanism of deposition of the sediments. In addition, the Miocene tectonic and volcanic event widespread in the western margin of the Pacific Ocean must have been unexpectedly intense to have left such a record in the abyssal environment.

\section{ACKNOWLEDGMENTS}

Sincere thanks are due to the Leg 129 Scientific Party and ODP Technical and Operations staff. We are grateful to D. A. Barnes, A. Fisher, and an anonymous reviewer for their constructive comments and careful English improvement of the manuscript. A.M.K. would like to sincerely acknowledge Y. Lancelot and J. L. Crovisier for helpful discussions. The analytical work was performed using the facilities at Centre de Géochimie de la Surface (CNRS), Strasbourg. This study was supported by a INSU-IST Grant, 90/ATP/781 AP90803911-GEO 307 to A.M.K.

\section{REFERENCES}

Abe, H., and Aoki, M., 1976. Experiments on the interaction between $\mathrm{Na}_{2} \mathrm{CO}_{3}$ $\mathrm{NaHCO}_{3}$ clinoptilolite tuff, with references to analcimization around Kuroko-type mineral deposits. Chem. Geol., 17:89-100.

Alt, J., Honnorez, J., Laverne C., and Emmermann, R., 1986. Hydrothermal alteration of a $1 \mathrm{~km}$ section through the upper oceanic crust, Deep Sea Drilling Project Hole 504B: mineralogy, chemistry and evolution of seawater-basalt interactions. J. Geophys. Research, 91:10309-10335.

Badalov, S. T., and Turesebekov, A., 1968. Extent and genetic significance of sedimentary metasomatic and vein sulfate minerals in the Karamazar (Uzbek SSR and Tadzhik SSR). Doklady Akad. Nauk SSSR, 178:1369-1370.

Baker, P. A., Gieskes, J. M., and Elderfield, H., 1982. Diagenesis of carbonate in deep-sea sediments: evidence from $\mathrm{Sr} / \mathrm{Ca}$ ratios and interstitial dissolved $\mathrm{Sr}^{2+}$ data. J. Sediment. Petrol., 52:71-82.

Besnus, Y., and Rouault, R., 1973. Une méthode d'analyse de roches au spectromètre d'arc à lecture directe par un dispositif d'électrode rotative. Analusis, 2:111-116.

Besse, D., Desprairies, A., Jehanno, C., and Kolla, V., 1981. Les paragenèses de smectites et de zéolites dans une série pyroclastique d'âge éocène moyen de l'océan Indien (DSDP, Leg 26, Site 253). Bull. Mineral., 104:56-63.

Chukhrov, F. V., 1972. Some data on sulfur isotope ratios in natural waters, sediments and ores. 24th Int. Geophys. Congr., 10:232-236.

Collot, J.-Y., Greene, H. G., Stokking, L. B., et al., 1992. Proc. ODP, Init. Repts., 134: College Station, TX (Ocean Drilling Program).

Crovisier, J. L., Honnorez, J., and Eberhart, J. P., 1987. Dissolution of basaltic glass in seawater: mechanism and rate. Geochim. Cosmochim. Acta, 51:2977-2990.

Desprairies, A., and Jehanno, C., 1983. Paragenèses minérales liées à des interactions basalte-sédiment-eau de mer. Sci. Geol. Bull., 36:93-110.

Eberhart, J. P., 1989. Analyse Structurale et Chimique des Matériaux: Paris (Dunod Ed.)

Edge, R. A., and Taylor, HF.W., 1971. Crystal structure of thaumasite, $\left[\mathrm{Ca}_{3}\right.$ $\left.\mathrm{Si}(\mathrm{OH})_{6}-12 \mathrm{H}_{2} \mathrm{O}\right]\left(\mathrm{SO}_{4}\right)\left(\mathrm{CO}_{3}\right)$. Acta Cryst., B27:594-601.

Effenberger, H., Kirfel, A., Will, G., and Kobetz, E., 1983. A further refinement of the crystal structure of thaumasite, $\mathrm{Ca}_{3} \mathrm{Si}(\mathrm{OH})_{6} \mathrm{CO}_{3} \mathrm{SO}_{4}^{-12} \mathrm{H}_{2} \mathrm{O}$. Neues. Jahrb. Mineral. Monatsh., H2:60-68.

Federico, M., 1970. Un inconsueto deposito di thaumasite fra i tuffi del cratere di Prata Porci (Colli Albani). Period. Miner., 39A:149-167.

France-Lanord, C., Karpoff, A. M., Michard, A., and the Leg 129 Shipboard Scientific Party, 1991. Diagenetic control on interstitial water chemistry in volcaniclastic sediments of NW Pacific: ODP Leg 129. EUG VI-Terra Abstract, 3:42,467.

Giampaolo, C., 1986. Dehydration kinetics of thaumasite at ambient pressure. Neues. Jahrb, Mineral. Monatsh., H3:126-134.

Gottardi, G., and Galli, E., 1985. Natural Zeolites: Berlin (Springer-Verlag).

Graham, D. W., Bender, M. L., Williams, D. F., and Keigwin, L. D., Jr., 1982. Strontium-calcium ratios in Cenozoic planktonic foraminifera. Geochim. Cosmochim. Acta, 46:1281-1292.

Hentschel, G., 1979. Hydrothermale minerale im basalt von Ortenberg (Vogelsberg). Geol. Jahrb. Hessen, 107:193-196.
Honnorez, J., 1981. The aging of the oceanic crust at low temperature. In Emiliani, C. (Ed.), The Sea (Vol. 7): The Oceanic Lithosphere: New York (Wiley), 7:525-587.

Hunter, D., 1988. Lime-induced heave in sulfate-bearing clay soils. J. Geotech. Eng., 114:150-167.

lijima, A., and Harada, K., 1969. Authigenic zeolites in zeolite palagonite tuffs on Oahu, Hawaii. Am. Mineral., 54:192-197.

lijima, A., and Utada, M., 1966. Zeolites in sedimentary rocks, with references to the depositional environments and zonal distribution. Sedimentology, 7:327-357.

Karpoff, A. M., 1980. The sedimentary deposits of Suiko seamount (Leg 55, Site 433): from the reef environment to the pelagic sedimentation. In Jackson, E. D., Koizumi, I., et al., Init. Repts DSDP, 55: Washington (U.S. Govt. Printing Office), 491-501.

1989. Les faciès pélagiques condensés Cénozoiques des océans Pacifique et Atlantique: témoins des grandes crises géodynamiques [Thèse Doc. Sci.]. Univ. Louis Pasteur, Strasbourg.

Karpoff, A. M., France-Lanord, C., Duplay, J., Crovisier, J. L., and Alt, J., 1991. La paragenèse d'altération inusuelle à thaumasite des tuffs miocènes du Bassin des Mariannes (Site 802, Leg 129). Bull. Liaison Soc. Fr: Miner. Crist., 2:41.

Karpoff, A. M., Peterschmitt, I., and Hoffert, M., 1980. Mineralogy and geochemistry of sedimentary deposits on Emperor seamounts, Sites 430, 431, and 432: authigenesis of silicates, phosphates and ferromanganese oxides. In Jackson, E. D., Koizumi, I., et al., lnit. Repts. DSDP, 55: Washington (U.S. Govt. Printing Office), 463-489.

Kastner, M., 1976. Diagenesis of basal sediments and basalts of Sites 322 and 323, Leg 35, Bellingshausen Abyssal Plain. In Hollister, C. D., Craddock, C., et al., Init. Repts. DSDP. 35: Washington (U.S. Govt. Printing Office), 513-527.

-1981 . Authigenic silicates in deep-sea sediments: formation and diagenesis. In Emiliani, C. (Ed.), The Sea (Vol. 7): The Oceanic Lithosphere: New York (Wiley), 915-980.

Knill, D. C., 1960. Thaumasite from Co. Down, Northern Ireland. Mineral. Mag., 32:416-418.

Lafaille, A., and Protas, J., 1970. Nouvelles données sur la structure de la thaumasite. C. R. Acad. Sci. Ser. 2, 270:2151-2154.

Lancelot, Y., Larson, R. L., et al., 1990. Proc. ODP. Init. Repts., 129: College Station, TX (Ocean Drilling Program).

Malley, P., Juteau, T., and Blanco-Sanchez, J. A., 1983. Hydrothermal alteration of submarine basalts: from zeolitic to spilitic facies in the upper triassic pillow-lavas of Antalya, Turkey. Sci. Geol. Bull., 36:139-163.

Moncure, G., Surdam, R. C., and McKague, H. L., 1981. Zeolite diagenesis below Pahute Mesa, Nevada Test site. Clays Clay Min., 29:385-396.

Mumpton, F. A. (Ed.), 1977. Mineralogy and geology of natural zeolites. Mineral. Soc. Am., Short Course Notes, 4:1-233.

Noack, Y., 1983. Occurrence of thaumasite in a seawater-basalt interaction, Mururoa atoll (French Polynesia, South Pacific). Mineral. Mag., 47:47-50.

Nordenskjöld, A. E., 1878. Sur une nouvelle espèce minérale nommée thaumasite. C. R. Acad. Sci. Ser. 2, 87:313-314.

Parson, L., Hawkins, J., Allen, J., et al., 1992. Proc. ODP, Init. Repts., 135: College Station, TX (Ocean Drilling Program).

Paulitsch, P., 1973. Thaumasit im Basalt von Klöch, Steiermark. Aufschluss, 24:266-268.

Petzing, J., and Chester, R., 1979. Authigenic marine zeolites and their relationship to global volcanism. Mar. Geol., 29:253-271.

Postl, W., and Walter, F., 1983. Ettringit und Thaumasit aus dem nephelinbasanit von Klöch, Steiermark. Mitt. Abt. Mineral., 51:329-332.

Samuel, J., Rouault, R., and Besnus, Y., 1985. Analyse multiélémentaire standardisée des matériaux géologiques en spectrométrie d'emission par plasma à couplage inductif. Analusis, 13:312-317.

Sand, L. B., and Mumpton, F. A. (Eds.), 1978. Natural Zeolites: Occurrence, Properties, Use: New York (Pergamon Press).

Sheppard, R. A., and Gude, A. J., 1969. Diagenesis of tuffs in the Barstow formation, Mud Hills, San Bernardino County, California. Geol. Surv. Prof. Pap. U.S., 634.

Shipboard Scientific Party, 1990. Site 802. In Lancelot, Y., Larson, R. L., et al., Proc. ODP, Init. Repts., 129: College Station, TX (Ocean Drilling Program), 171-243.

Taylor, B., Fujioka, K., et al., 1990. Proc. ODP, Init. Repts., 126: College Station, TX (Ocean Drilling Program). 
Vogt, T., 1938. Thaumasite from Sulitelma, Norway. Nork. Geol. Tidsskr., 18:291-304.

von Rad, U., Frenzel, G., and Mühe, R., 1990. Origin and alteration of submarine volcaniclastic rocks from the Lau and North Fiji Basins (SW Pacific, SO-35 Cruise). Geol. Jahrb., D92:341-393.

Walton, A. W., 1975. Zeolitic diagenesis in Oligocene volcanic sediments, Trans-Pecos Texas. Geol. Soc. Am. Bull., 86:615-624.

Wilson, M. J., 1978. Occurrence of thaumasite in weathered furnace slag, Merthyr Tydfil. Mineral. Mag., 42:290-291.

Wirsching, U., 1981. Experiments on hydrothermal formation of calcium zeolites. Clays Clay Min., 29:171-183.
Wood, D. A., Gibson, I. L., and Thompson, R. N., 1976. Elemental mobility during zeolite facies metamorphism of the tertiary basalts from Eastern Iceland. Contrib. Mineral. Petrol., 55:241-254.

Date of initial receipt: 19 August 1991

Date of acceptance: 10 February 1992

Ms 129B-113 

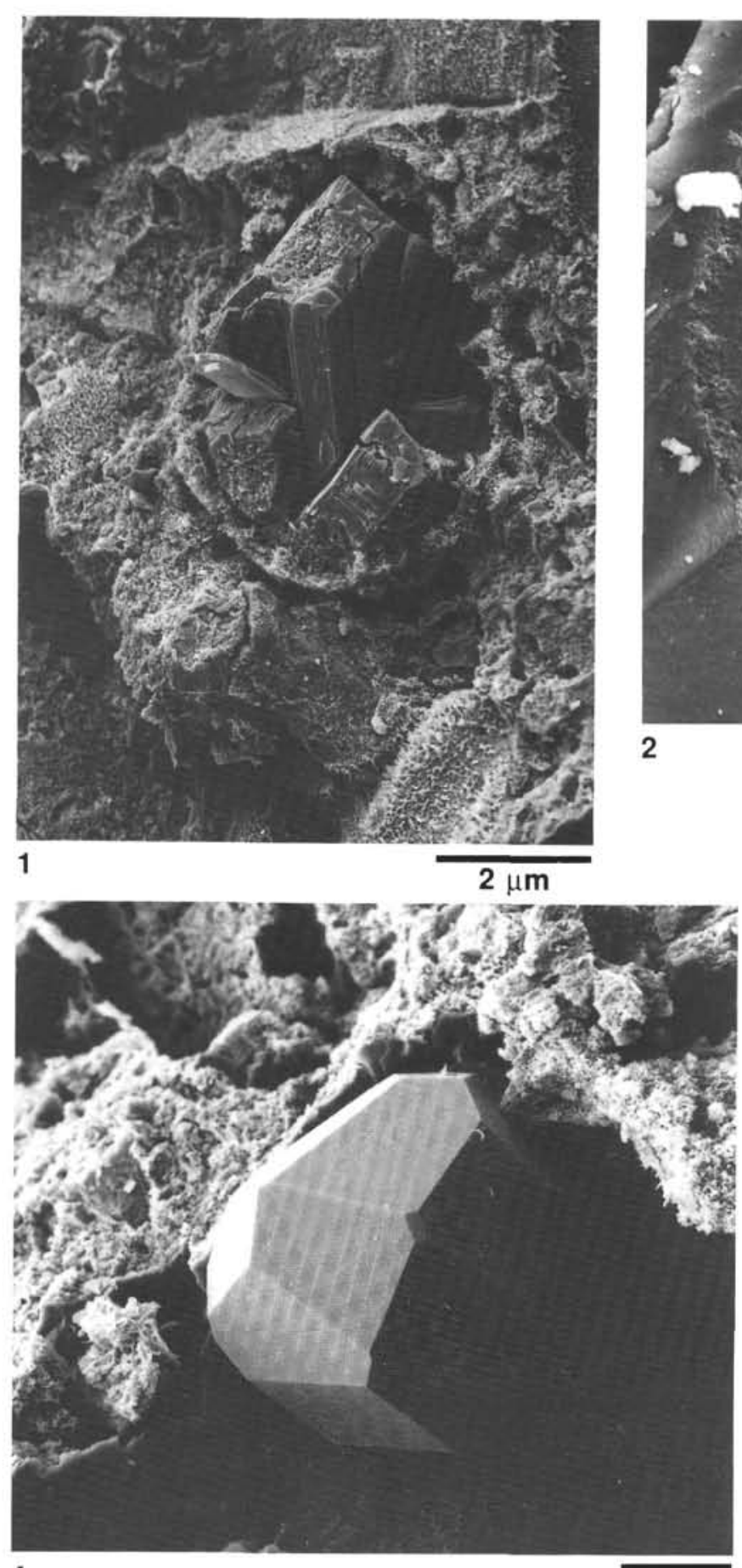

4

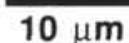

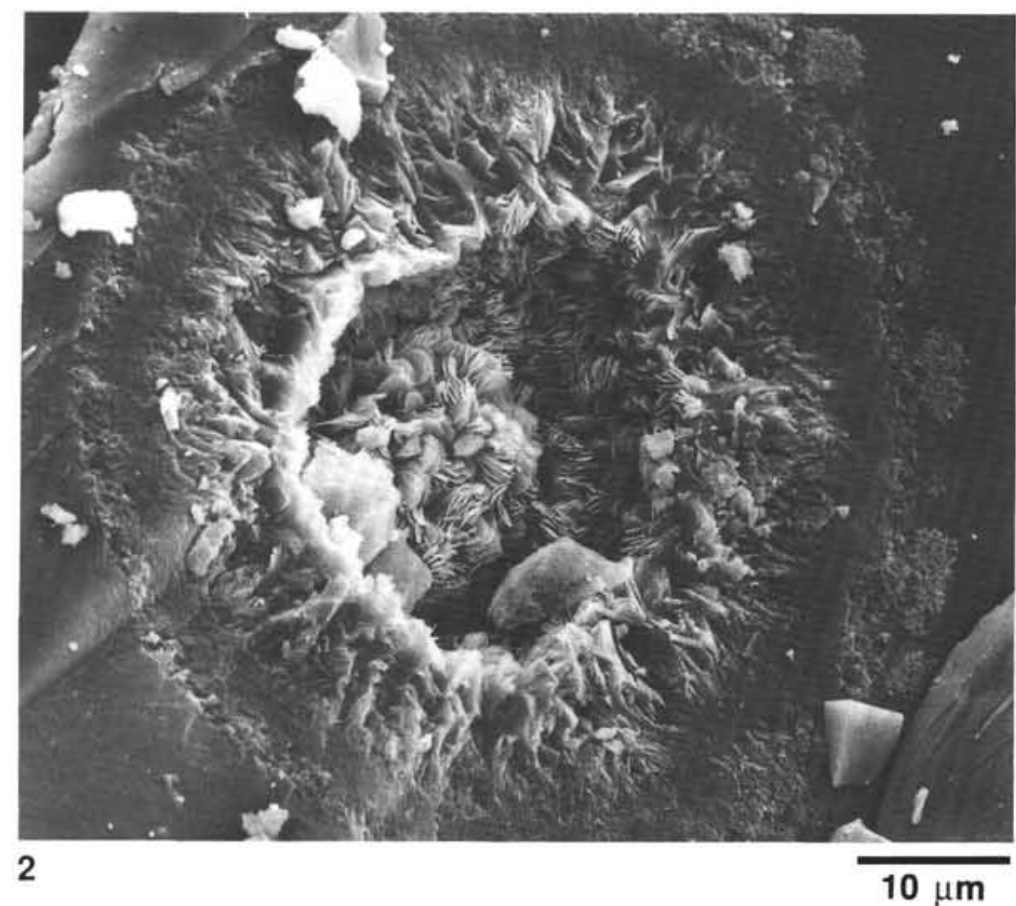

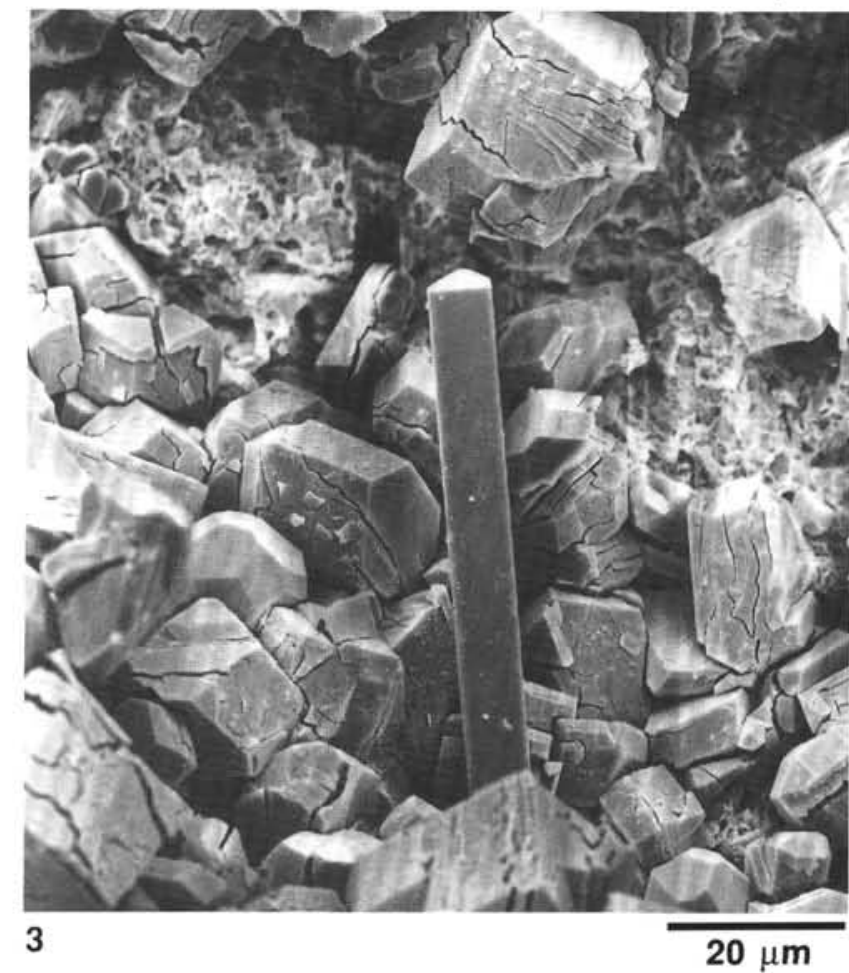

Plate 1. SEM photomicrographs of Miocene tuff from Site 802. 1. Argillized radiolarian ghost, filled with K-zeolite, from cemented clayey tuff interval (Sample 129-802A-22R-1, 21-25 cm). 2. Vesicle in a glass clast from the well-cemented, black interval, with successive rings of palagonite and well-crystallized Mg-smectite (Sample 129-802A-15R-1, 100-104 cm). 3. Dodecahedral analcime crystal in small void into clay matrix of the cemented clayey tuff interval (Sample 129-802A-22R-1, 21-25 cm). 4. Sole rod of Na-zeolite among small crystals of analcime (Sample 129-802A-23R-1, 14-17 cm). 

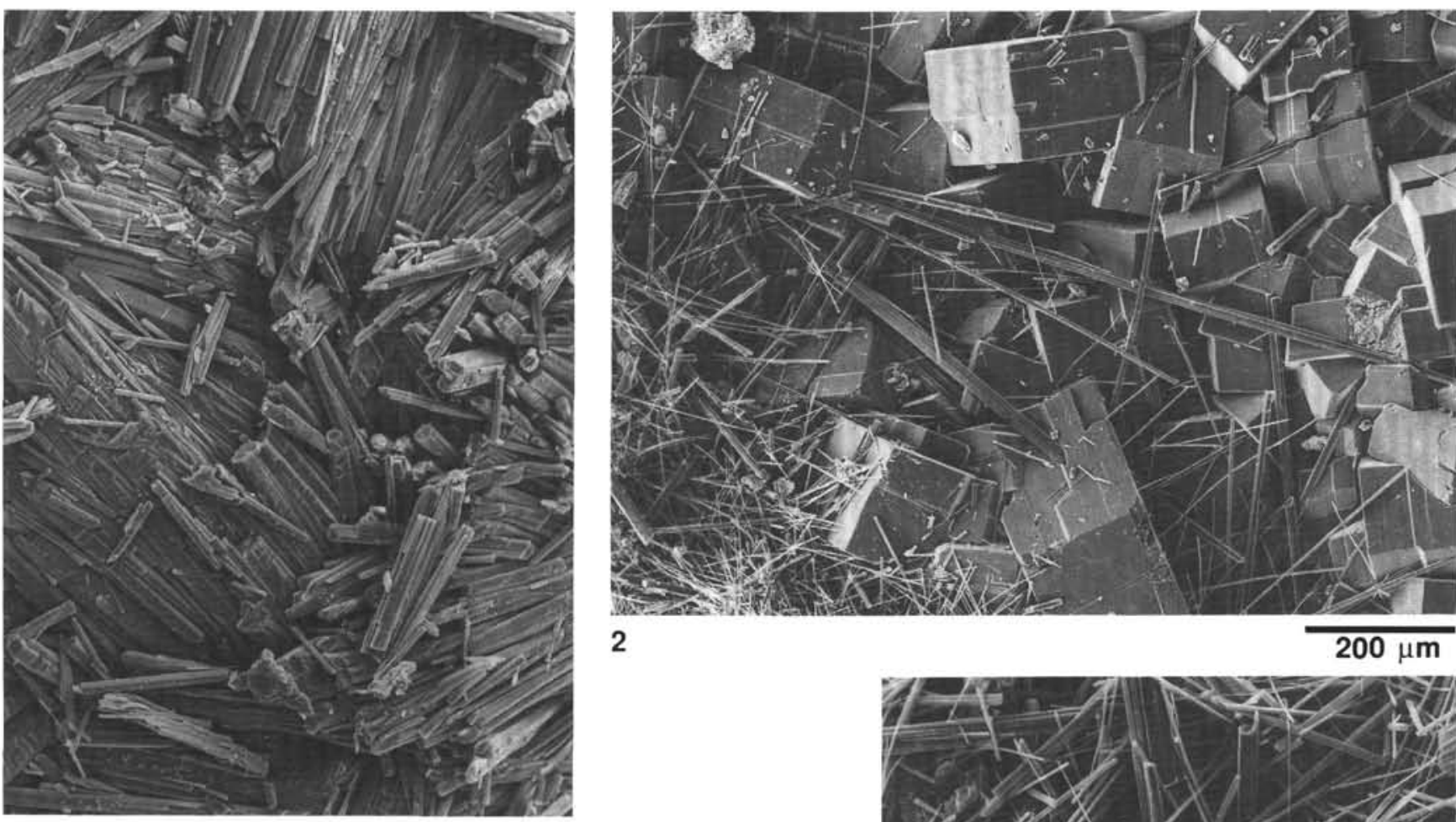

1

$50 \mu \mathrm{m}$

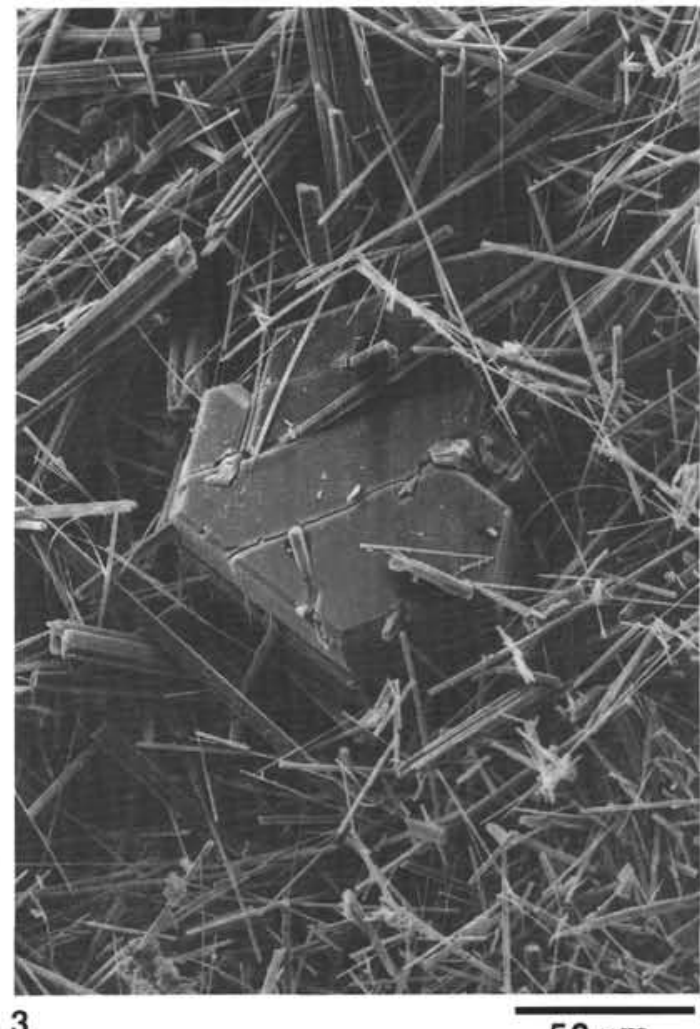

4

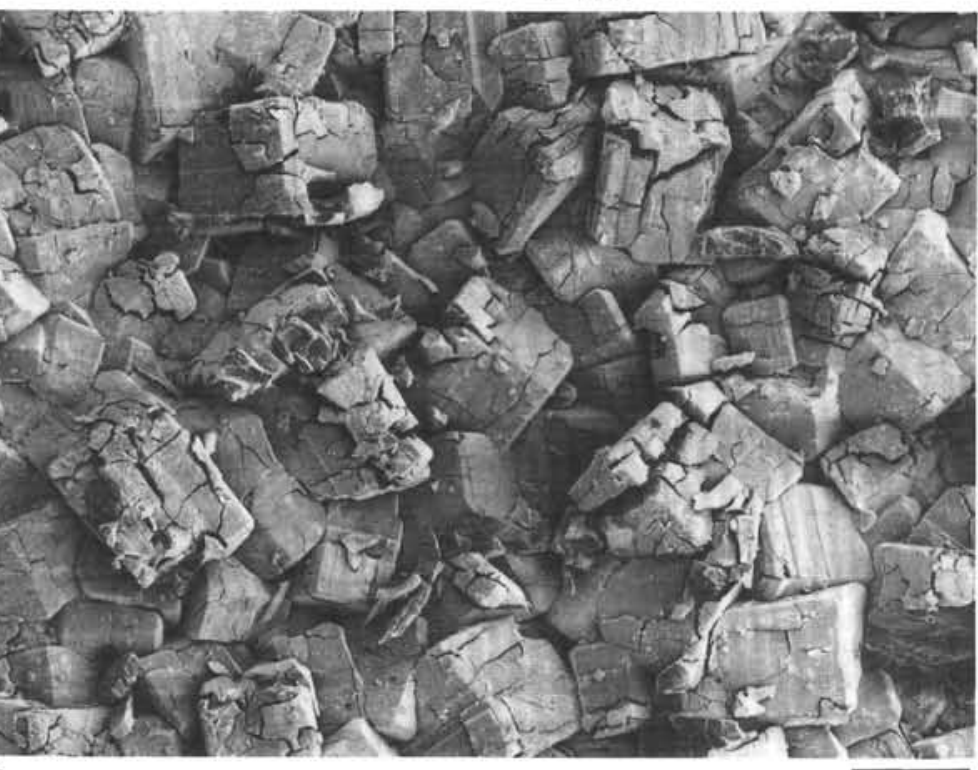

$\overline{200 \mu \mathrm{m}}$

$50 \mu \mathrm{m}$

Plate 2. SEM photomicrographs of the fracture and fissure fillings in Miocene tuff from Site 802. 1. Massive vein made of thick fibers of thaumasite (fracture-type 1 in Figure 3B; Sample 129-802A-16R-1, $33 \mathrm{~cm}$ ). 2. Cogenetic thaumasite long fibers and chabazite rhombs in a millimeter-thick fissure vein similar as type 2 in Figure 3B (Sample 129-802A-15R-2, $3 \mathrm{~cm}$ ). 3. Same sample as in (2): internal zone of the fissure with prevalent thaumasite fibers and herschelite crystal (a Na-chabazite). 4. Very thin fissure coated by fragile crystals of herschelite, (fissure-type 3 in Figure 3B; Sample 129-802A-16R-1, 30 cm). 